\title{
Expedition 311 synthesis: scientific findings ${ }^{1}$
}

\author{
M. Riedel, ${ }^{2}$ T.S. Collett, ${ }^{3}$ and M. Malone ${ }^{4}$
}

\section{Chapter contents}

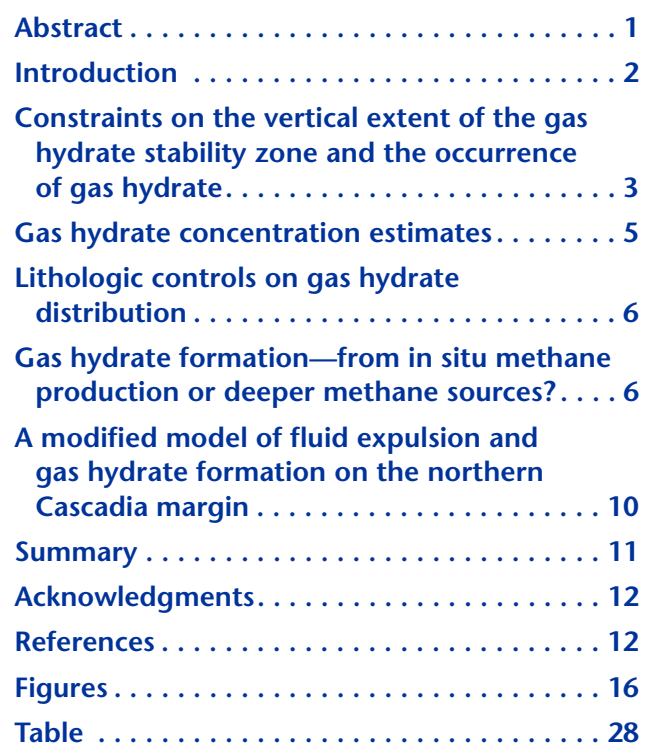

${ }^{1}$ Riedel, M., Collett, T.S., and Malone, M., 2010. Expedition 311 synthesis: scientific findings. In Riedel, M., Collett, T.S., Malone, M.J., and the Expedition 311 Scientists, Proc. IODP, 311: Washington, DC (Integrated Ocean Drilling Program Management International, Inc.). doi:10.2204/iodp.proc.311.213.2010 ${ }^{2}$ Natural Resources Canada, Geological Survey of Canada, 9860 West Saanich Road, Sidney BC V8L 4B2, Canada.mriedel@nrcan.gc.ca

${ }^{3}$ U.S. Geological Survey, Denver Federal Center, Denver CO 80225, USA.

${ }^{4}$ Integrated Ocean Drilling Program, 1000

Discovery Drive, College Station TX 77845, USA.

\section{Abstract}

Integrated Ocean Drilling Program Expedition 311 was conducted to study gas hydrate occurrences and their evolution along a transect spanning the entire northern Cascadia accretionary margin. A transect of four research sites (U1325, U1326, U1327, and U1329) was established over a distance of $32 \mathrm{~km}$, extending from Site U1326 near the deformation front to Site U1329 at the eastern limit of the inferred gas hydrate occurrence zone. In addition to the transect, a fifth site (U1328) was established at a cold vent setting with active fluid and gas expulsion, which provided an opportunity to compare regional pervasive fluid-flow regimes to a site of focused fluid advection. In this synthesis, a revised gas hydrate formation model is proposed based on a combination of geophysical, geochemical, and sedimentological data acquired during and after Expedition 311 and from previous studies. The main elements of this revised model are as follows:

1. Fluid expulsion by tectonic compression of accreted sediments at nonuniform expulsion rates along the transect results in the evolution of variable pore water regimes across the margin. Sites closer to the deformation front are characterized by pore fluids enriched in dissolved salts at depth, where zeolite formation from ash diagenesis is dominant. In contrast, the landward portion of the margin shows a freshening of pore fluids with depth as a result of the progressive overprinting of diagenetic salt generation with freshwater generation from the smectite-to-illite transition at greater depth.

2. In situ methane produced by microbial $\mathrm{CO}_{2}$ reduction within the gas hydrate stability zone is the prevalent gas source for gas hydrate formation.

3. Some minor methane advection from depth is required overall to explain the occurrence of gas hydrate (and the associated downhole isotopic signatures of $\mathrm{CH}_{4}$ and $\mathrm{CO}_{2}$ ) within the sediments of the accretionary prism and the absence of gas hydrate within the abyssal plain sediments. In contrast, methane migrating from depth is a dominant source for gas hydrate formation at the cold vent Site U1328 (Bullseye vent).

4. Gas hydrate preferentially forms in coarser grained sandy/silt turbidites, resulting in very high local gas hydrate concentrations. Typically, gas hydrate occupies $<5 \%$ of the pore space throughout the gas hydrate stability zone. Higher gas hydrate saturations were observed in intervals with abundant coarse- 
grained sand layers and within fault-controlled fluid and gas migration conduits at the cold vent Site U1328.

\section{Introduction}

Integrated Ocean Drilling Program (IODP) Expedition 311 was conducted on the northern Cascadia margin (Fig. F1) during September and October 2005 (see the "Expedition 311 summary" chapter). Expedition 311 was the third deep drilling expedition on the Cascadia margin with a major gas hydrate research objective. The first drilling on the Cascadia margin was conducted in 1992, when Ocean Drilling Program (ODP) Leg 146 (Westbrook, Carson, Musgrave, et al., 1994) established three drill sites on the northern Cascadia margin (Sites 888, 889, and 890) as well as Site 892 on Northern Hydrate Ridge, offshore of Oregon (southern Cascadia margin). In 2002, ODP Leg 204 (Tréhu, Bohrmann, Rack, Torres, et al., 2003) followed with a dedicated study of Southern Hydrate Ridge (SHR). During this expedition, nine closely spaced drill sites were established in a short transect across the ridge to study the summit of SHR, where seafloor gas hydrate had been discovered (e.g., Suess et al., 1999).

Expedition 311 was designed to study gas hydrate occurrences along a transect across the northern Cascadia margin, and thus the expedition augmented the geographical range of previous gas hydrate studies on the Cascadia margin. A transect of four sites (U1325, U1326, U1327, and U1329) was established to characterize the different geologic and tectonic settings of gas hydrate occurrence across the margin, spanning a distance of $32 \mathrm{~km}$ from Site U1326 near the deformation front to the landward Site U1329 at the eastern limit of the previously inferred gas hydrate occurrence. These drill sites roughly follow multichannel seismic (MCS) Line 89-08, which was acquired in 1989 as part of the presite survey for Leg 146 (Fig. F2). Projecting the previously established deep basin Site 888 onto the end of the new transect extended the profile to $>40 \mathrm{~km}$. In addition to the transect sites, a fifth site (U1328) was established at a cold vent with active fluid and gas expulsion. This provided an opportunity to compare regional pervasive fluid-flow regimes to a site of focused fluid flow.

The main goal of Expedition 311 was to test geologic gas hydrate formation models and associated model parameters in subduction zone accretionary prisms, especially those that account for the formation of concentrated gas hydrate occurrences driven by upward fluid and methane transport. The detailed objectives of the expedition were to (1) study the formation of natural gas hydrate in marine sediments;
(2) determine the mechanisms that control the nature, magnitude, and distribution of the gas hydrate occurrence; (3) find the pathways of upward fluid migration required to form large concentrations of gas hydrate; (4) examine the effect of gas hydrate on the physical properties of the host sediment; and (5) investigate the microbiology and geochemistry associated with the gas hydrate occurrence.

Prior to Expedition 311, a general model for gas hydrate formation by removal of methane from upwardly expelled fluids was generally accepted for the Cascadia margin (Hyndman and Davis, 1992). In this model, dissolved microbial methane, inferred to be produced over a thick sediment section, migrates vertically and forms gas hydrate when it enters the stability field. Gas hydrate concentration is predicted to be greatest just above the base of gas hydrate stability, seismically defined by the bottom-simulating reflector (BSR). A model was also proposed for how free gas and the resulting BSR are formed as the base of gas hydrate stability moves upward because of post-Pleistocene seafloor warming, uplift, and sediment deposition (e.g., Paull and Ussler, 1997; von Huene and Pecher, 1998). In addition, physical and mathematical models have been developed for the formation of gas hydrate from upward methane advection and diffusion (e.g., Xu and Ruppel, 1999).

Evidence that focused fluid/gas flow and associated gas hydrate formation contrasts with the diffuse, regional fluid-flow regime has been identified on the northern Cascadia margin at various locations. The most studied site, referred to as Bullseye vent, is an active cold vent field associated with near-surface gas hydrate occurrences and was drilled as Site U1328 during Expedition 311. These vents were shown to be associated with fault-related conduits for focused fluid and/or gas migration and with massive gas hydrate formation within the fault zone (Riedel et al., 2002, 2006).

In this synthesis, we first report integrated findings on the distribution and magnitude (concentration, $\mathrm{S}_{\mathrm{h}}$ ) of gas hydrate, as determined from logging data and core-derived pore water freshening (Chen et al.; Chen, 2006; Malinverno et al., 2008; Ellis et al., 2008). We then show the results of sedimentological and geochemical core studies as well as infrared (IR) imaging of the recovered core, demonstrating the lithological control on gas hydrate occurrences on the northern Cascadia margin (Torres et al., 2008; Hashimoto and Minamizawa; Wang, 2006). These results are the basis for discussion of the underlying fluid-flow model along the Expedition 311 transect. We combine results from downhole logging data and detailed pore fluid and gas chemistry data (Torres and Kastner; Pohlman et al., 2009; Lu et al., 2008; 
Kim and Lee) to develop an updated model that can explain the occurrences and distribution of gas hydrates along the Cascadia margin.

\section{Constraints on the vertical extent of the gas hydrate stability zone and the occurrence of gas hydrate}

A primary objective of Expedition 311 was to define the vertical extent of the gas hydrate stability zone (GHSZ) and the occurrence of gas hydrate. The depth of the base of gas hydrate stability zone (BGHSZ) was estimated before drilling by assuming that the seismically observed BSR represents the BGHSZ. Among the proxies used to determine the depth of the BGHSZ and also to define the occurrence of gas hydrate and to compare these occurrences to the predicted depth of the BSR are

- Downhole temperature measurements,

- Well-log measurements of $P$-wave velocity and electrical resistivity,

- Degassing experiments on pressure cores,

- Pore water chlorinity,

- IR imaging, and

- Hydrocarbon gas ratios (e.g., $\mathrm{C}_{1} / \mathrm{C}_{2}$ and i- $\mathrm{C}_{4} / \mathrm{n}-\mathrm{C}_{4}$ ) of the void gas.

There are notable differences between the individual techniques because each is highly dependent on how the measurement is conducted and the resolution or sensitivity of the particular measurement and because the results are biased by core recovery (IR imaging, pore water chemistry, and gas chemistry) and sampling density (e.g., the frequency of temperature tool deployments and linear regression analysis). The results of the various techniques used to estimate the BGHSZ and predict the occurrence of gas hydrate at all sites are shown in Table T1.

The expedition included 36 temperature tool deployments to characterize the thermal regime of all five drilled sites. Three standard IODP temperature tools were deployed, including the Advanced Piston Corer Temperature Tool (APCT, as well as the newer version [APCT-3; Heesemann et al.], 20 times), the DavisVillinger Temperature Probe (DVTP, 11 times), and the Davis-Villinger Temperature-Pressure Probe (DVTPP, 5 times). A compilation of the in situ temperature estimates from Expedition 311 is compared to previous results from Site 889 (Fig. F3). The temperature data acquired were used to estimate the depth of the BGHSZ at each site. A pure methane gas chemistry was assumed for the in situ hydrate (confirmed by shipboard analysis), and interstitial water salinities from the onboard analysis of core samples were used in the calculations. Furthermore, the pore pressure gradient was assumed to be hydrostatic $(9.795 \mathrm{kPa} / \mathrm{m})$ and the geothermal gradients linear. Results of all regression analyses at all sites are summarized in Table T1.

One of the more important methods used to identify and quantify the occurrence and extent of gas hydrate is pressure core degassing. Pressure cores retrieved at in situ pressure conditions were used to determine gas hydrate quantity (see also below) using mass balance calculations (e.g., Dickens et al., 1997; Milkov et al., 2004). Pressure cores were also used to investigate gas hydrate distribution using nondestructive physical property measurements of the cores at in situ pressures. Pressure coring is crucial for understanding the concentrations of gas hydrate and free methane gas in marine sediments, their nature and distribution, and their effect on the intrinsic properties of the sediment. Pressure cores were collected using the IODP Pressure Core Sampler (PCS), the Fugro Percussion Corer (FPC), and the HYACE Rotary Corer (HRC). Combined results from all degassing experiments at the five sites visited are shown in Figure F4.

\section{Top of gas hydrate occurrence}

Gas hydrate occurrence, as inferred from downhole logs, IR core images, pore water chlorinity freshening, and physical recovery in cores, was much shallower than expected based on previous studies at this margin. At Site U1326, gas hydrate was first recovered at $\sim 47$ meters below seafloor (mbsf), and, at Site U1325, gas hydrate was inferred from the electrical resistivity logs to occur as shallow as 73 mbsf. In contrast, at Site U1327, gas hydrate was first recovered at 111 mbsf. Site U1329 did not show any significant evidence of gas hydrate content; however, a small pore water freshening trend at 123 mbsf may indicate low concentrations of gas hydrate just above the BSR. The apparent progressive decrease in the top depth of gas hydrate occurrence along the transect was investigated by Malinverno et al. (2008) and Torres and Kastner, who used one-dimensional geochemical diffusion modeling to explain the observed landward deepening of the top of gas hydrate occurrence on a site-by-site basis. The model computes methane concentration in the pore fluid for a given in situ bacterial methane production rate, sedimentation rate, and fluid advection velocity. Modeling shows that lower rates of sedimentation or fluid advection result in lower methane concentrations with depth and thus a deepening of the first occurrence of gas hydrate. Sedimentation rates decrease landward along the coring transect (Akiba et al.), 
corresponding to an increase in depth to the top of the first gas hydrate occurrence. Fluid advection rates, due to dewatering of the accretionary wedge, are expected to first increase with distance from the deformation front, to a maximum of $\sim 15 \mathrm{~km}$ into the accretionary prism (Hyndman and Davis, 1992), and then progressively decrease farther landward. A combination of these two mechanisms can explain the deepening of the top of the gas hydrate occurrence along the transect. However, considerable variability along the margin is induced by locally variable sedimentation rates and erosion along uplifted ridges. Also, because gas hydrate forms predominantly in sandy turbidite sediments (see next section), the presence of an appropriate host strata further affects gas hydrate occurrence.

Fluid advection rates required for modeling the thickness of the gas hydrate occurrence zone may be constrained by values of sulfate (and thus methane) flux obtained from reactions of sulfate and methane at the sulfate-methane transition zone (e.g., Borowski et al., 1996). However, there is a complex, uncertain correlation between the depth of the sulfate-methane transition zone and the thickness of the gas hydrate occurrence when data from various sites of gas hydrate are compared globally (Kastner et al., 2008; Dickens and Snyder, 2009; Torres and Kastner).

The coupled microbial reactions of anaerobic oxidation of methane (AOM) are also a sink for sulfate, and the presence of AOM can best be determined from $\delta^{13} \mathrm{C}$ isotopic data. Evidence for AOM is present at all sites studied during Expedition 311, and results from the northern Cascadia margin compare well with observations made at SHR during Leg 204 (Claypool et al., 2006).

\section{The base of gas hydrate stability zone and the nature of the bottom-simulating reflector}

A regional BSR was observed along the entire northern Cascadia margin. This BSR is believed to represent the base of gas hydrate stability and thus to mark the transition from gas hydrate-bearing sediments and sediments containing some free gas. Associated changes in the physical properties of the sediment at the BSR from (possibly) higher to lower $P$-wave velocity are the cause of this prominent seismic reflection. Combined geophysical data analyses have shown that the amount of free gas required to yield the BSR reflection strength observed on the northern Cascadia margin is $<1 \%$ of the pore space (e.g., Hyndman et al., 2001; Yuan et al., 1996, 1999) and that the free gas zone is relatively thin $(<10 \mathrm{~m}$; Chapman et al., 2002).

In order to trap some free gas at the BGHSZ, a temporal permeability barrier of some sort most likely exists. At all sites investigated during Expedition 311, the gas hydrate concentration is $<5 \%$ (of the pore space) on average; additionally, no evidence was found for a systematic and regionally distributed increase in gas hydrate concentration just above the BSR, as was previously suggested (e.g., Hyndman et al., 2001).

It is also important to note that the upward movement of gas bubbles in porous sediments can be restricted by capillary forces. For free gas to pass through the pore throat of sediment, the gas pressure inside the bubble must overcome the capillary pressure. Vertical migration of bubbles requires an interconnected gas phase and a gas column thick enough that the pressure difference between gas bubbles and pore water (due to different densities) can overcome the capillary pressure in the pore throats (Schowalter, 1979). Gas bubbles beneath the BGHSZ can also be stuck or trapped in the pore space of a fine-grained sediment with a gas saturation of only a few percent (as estimated at the northern Cascadia margin).

Thus, as little as a few percent gas hydrate in a clayrich, low-permeability sediment could already be an effective barrier or at least a boundary that impedes gas and water from flowing across this horizon and results in a concentration gradient across the boundary with free gas being trapped.

As described by Haacke et al. (2007), gas hydrate recycling at the BGHSZ is a common phenomenon at convergent margins. The continued growth of the accretionary prism (tectonic uplift) combined with sedimentation processes (erosional and depositional) results in continuous changes in the BGHSZ and thus the dissociation of gas hydrate and the release of free gas and water. The resulting free gas zone below the BGHSZ is also much thinner compared to passive margins where the free gas zone is generally thicker (Haacke et al., 2007). It is possible that the free gas migrates back into the GHSZ (if buoyant enough, or, for example, by processes such as the self-generated permeability described by Flemings et al., 2003); however, in most cases, a residual amount (concentrations of a few percent or less) of free gas is trapped by capillary forces in the pore space. 


\section{Gas hydrate concentration estimates}

Gas hydrate concentrations were determined during Expedition 311 using mainly downhole loggingwhile-drilling (LWD) electrical resistivity data as well as wireline electrical resistivity log data (see the "Expedition 311 summary" chapter). Procedures followed standard Archie analyses (Archie, 1942; Collett and Ladd, 2000), and a detailed description of the methods and assumptions involved can be found in the "Methods" chapter. More detailed analyses of gas hydrate concentrations from the downhole resistivity log data were conducted after the expedition by Malinverno et al. (2008) and Chen et al. Malinverno et al. (2008) presented a method to calculate gas hydrate concentrations from the direct comparison of core-derived salinity and downhole log data from Site U1325 that honors the spatial uncertainty in the measurements from different boreholes located $\sim 25 \mathrm{~m}$ apart. The technique was also applied to all other sites drilled along the transect. Chen et al. analyzed in detail the effect of porosity uncertainty on gas hydrate concentration estimates by comparing results obtained from density and neutron porosity calculations for all transect sites.

Seismically derived velocities (mainly $P$-wave velocity, $V_{\mathrm{P}}$ ) can also be used to calculate gas hydrate concentrations. Two studies were carried out by Goldberg et al. (2008) and Chen (2006) using wireline and LWD data to determine velocity log-based gas hydrate concentrations. Although both methods show generally comparable results, gas hydrate concentrations calculated from acoustic velocities are slightly higher than resistivity-based estimates. For the purpose of understanding geologic controls on the occurrence of gas hydrates, these differences were disregarded.

Additional constraints on gas hydrate concentrations were obtained from pressure core degassing experiments, as originally outlined by Dickens et al. (1997). A total of 16 PCS cores were recovered under in situ pressure conditions and yielded estimates of gas hydrate concentrations (Fig. F4). All of the results of the PCS degassing experiments are superimposed on the logging-derived results shown in Figure F5.

All data from Expedition 311 confirm that gas hydrate concentrations at the drill sites along the transect are generally relatively low $(<5 \%$ of the pore space) but locally can exceed $50 \%$ of the sediment pore space (especially at Site U1326, 50-120 mbsf, and Site U1327, 120-140 mbsf). A summary of resistivity data and derived gas hydrate concentrations $\left(S_{h}\right)$ from all five sites drilled during the expedition are shown in Figure F5. The results demonstrate that the highest gas hydrate concentrations are not found near the BGHSZ (i.e., just above the BSR), as was predicted by the preexpedition Hyndman and Davis (1992) pore fluid expulsion model.

The two key variables for estimating concentrations of in situ pore fluid constituents (i.e., not settings with gas hydrate in fractures) using the Archie calculations (in addition to porosity) are pore fluid salinity and geothermal gradient. Geothermal gradients were successfully determined from individual downhole temperature probe deployments at all sites except Site U1326 (where only one downhole deployment succeeded in a reliable measurement). Detailed results of each deployment can be found in the individual site chapters of this volume. Pore fluid salinities and chlorinity were carefully determined onboard to (a) establish the background trend in pore fluid salinity and (b) capture any gas hydrate present and determine the local gas hydrate concentration from the pore fluid freshening relative to the background trend.

Figure $\mathbf{F} 6$ shows the entire data set available for pore water chlorinity analyses at all sites. Sites U1325 and U1326 both exhibit increasing pore water chlorinity with depth, as opposed to the other three sites (U1327, U1328, and U1329), which all decrease in pore water chlorinity with depth. Previously, the entire freshening trend observed at Site 889 was attributed to the dissociation of gas hydrate upon recovery (Hyndman et al., 1999). In contrast, Kastner et al. (1995a) suggested some component of mixing with a deeper, fresher fluid source to account for the combined observations of the pore fluid geochemical profiles, thus resulting in reduced gas hydrate concentrations compared to the study by Hyndman et al. (1999). However, more recent data from Expedition 311 clearly show that only the discrete outliers can be attributed to gas hydrate recovered in the core because they were coincident with IR-inferred gas hydrate occurrences. In addition to the IR data acquired from cores within the first few minutes after recovery, a second IR camera was used in the onboard geochemistry laboratory to allow further detailed discrimination of gas hydrate in the recovered core (Fig. F5; see discussion in the next section for further details).

Despite evidence from IR imaging, some doubts remained about the cause of the freshening trend, as originally argued by Hyndman et al. (1999). Therefore, Chen et al. carried out the same analyses originally conducted by Hyndman et al. (1999) to simultaneously solve for the in situ pore water salinities as well as gas hydrate concentrations. The new application of the Archie analyses by Chen et al. using LWD and wireline data from Expedition 311 
verified that the measured pore water salinities generally follow the assumed background freshening trend.

\section{Lithologic controls on gas hydrate distribution}

During onboard analyses of the recovered core, it became evident that most of the gas hydrate recovered occurred in the coarser grained sandy turbidite sections (see the "Expedition 311 summary" chapter). Other forms of gas hydrate were recovered within veins and fractures, especially at the cold vent Site U1328, and will be discussed later in this report. Although previously observed on other expeditions (e.g., Ginsberg et al., 2000; Weinberger et al., 2005), and thus not fully unexpected, direct observation (visually and through IR imaging) of gas hydrate in sands on the Cascadia margin was systematically documented for the first time during Expedition 311. Furthermore, the relatively high amount of sand recovered at all sites (but especially Sites U1325 and U1326) was surprising compared to results from Leg 146.

The strongest evidence for the occurrence of gas hydrate within coarser grained sediment comes from IR imaging of recovered core segments, as described by Torres et al. (2008). Typically, 10-30 cm long wholeround segments were cut from the core and taken to the geochemistry laboratory for further analyses. Although historically the entire core section would have been mechanically squeezed after cleaning to collect pore water samples, the core section was first laid out and reimaged with an IR camera (Fig. F7). Cores with IR anomalies were further sampled for individual squeezing and pore water analyses. These analyses documented the preference for gas hydrate to be present in coarser grained sandy-to-silty turbidites, with only a very minor fraction present in fine-grained sediments. At Site U1325, the gas hydrate concentration is directly correlated to the sand content of the host sediment (Torres et al., 2008). However, Site U1326 samples contained a lower average gas hydrate concentration than what would be expected based on the amount of sand present in the sediments. This was interpreted by Torres et al. (2008) as indicative of an insufficient availability of methane to fully "charge" the sand to the maximum possible gas hydrate concentration (e.g., from reduced local in situ methane production rates).

In addition to the study by Torres et al. (2008), two other studies were conducted by Hashimoto and Minamizawa and Wang (2006) to analyze grain-size distribution at the Expedition 311 drill sites with linkages to gas hydrate occurrences. Wang (2006) also used soupy and mousselike sediment textures to further infer the presence of gas hydrate. A good correlation was found between the occurrence of inferred gas hydrate and the coarser grain fraction.

An interesting general question arises from observation of the strong lithologic control on gas hydrate occurring mainly in sands and the apparent deepening of the top of gas hydrate occurrence landward from the deformation front (as modeled by Malinverno et al., 2008): What defines the shallowest occurrence of gas hydrate? Is it the combination of in situ methane production, sedimentation, and methane advection rates or simply the limit in sand occurrence at a given depth?

Recently, Malinverno (2010) showed that if gas hydrate formation is inhibited in the small pores of fine-grained marine muds, microbial methane generated in these mud layers will stay in solution. This dissolved methane will instead be transported by diffusion into the coarser grained sand or silt layers, where it forms concentrated gas hydrate. As an example, sediments recovered at Site U1325 show a large abundance of sand and silt layers across the entire $300 \mathrm{~m}$ cored interval. An interval with a high abundance of sand layers occurs between 57 and 67 mbsf, where 40 individual sand layers were identified (see "Lithostratigraphy" in the "Site U1325" chapter). However, the shallowest gas hydrate at Site U1325 was inferred from the resistivity logs to be at $\sim 73$ mbsf. The first sand layer with gas hydrate was identified from IR images and pore water chlorinity freshening at $\sim 80$ mbsf. Combining these observations with the models by Malinverno (2010) and Malinverno et al. (2008) shows that the top of gas hydrate is a factor of overall in situ methane production and sedimentation rates and is not necessarily related to the amount of sand present (or lacking) in the system. Advection is not necessarily a requirement to form the observed concentrations of gas hydrate. However, if methane advection is added to the scenario, the top of gas hydrate remains at the same depth if in situ methane production is reduced proportionally.

\section{Gas hydrate formation-from in situ methane production or deeper methane sources?}

A general model for deep-sea gas hydrate formation by removal of methane from upwardly expelled fluids was developed by Hyndman and Davis (1992). In this model, mostly microbial methane produced over a thick sediment section pervasively migrates 
upward to form gas hydrate as it enters the stability zone. The gas hydrate concentration is therein predicted to be greatest just above the BSR associated with the BGHSZ.

With the five sites established during Expedition 311 and combinations of observations made during Leg 204 , there are now several data sets available to help modify and further develop the pore fluid expulsion model. These data sets include

- $\delta^{13} \mathrm{C}$ isotopic composition of methane and carbon dioxide gases from sediment core samples and gas from void spaces in the recovered cores (Pohlman et al., 2009), gas analyses from pressure core samples, and gas hydrate samples;

- $\delta^{13} \mathrm{C}$ isotope composition of the dissolved inorganic carbon (DIC) (Torres and Kastner);

- Pore fluid chlorinity and related fluid advection modeling (see the "Expedition 311 summary" chapter; Malinverno et al., 2008; Wortmann et al. 2008);

- Strontium (Sr) and lithium (Li) components of the pore water following earlier results from Legs 146 and 204 (Teichert et al., 2005; Kastner et al., 1995b); and

- Iodine, bromine, and ammonium pore fluid constituents (Lu et al., 2008).

\section{Inorganic pore water constituents and upward fluid migration constraints}

Downhole trends in inorganic pore water constituents (e.g., chlorinity) suggest a strong component of pore water migration from below with distinctly different source compositions (Fig. F6). This inferred upward pore water migration is a critical component of the dewatering process in the Cascadia accretionary prism, where the incoming ascending sediment section is deformed and squeezed by the tectonic processes that form the accretionary wedge. Modeling conducted by Malinverno et al. (2008) assumed relatively low advection rates (a maximum of $0.017 \mathrm{~cm} / \mathrm{y}$ was inferred), which is about an order of magnitude lower than rates used in previous studies (Bekins and Dreiss, 1992; Wang et al., 1993; Hyndman and Davis, 1992). Fluid advection modeling is also strongly dependent on accurate sedimentation rates. Sedimentation rates at the Expedition 311 transect sites were estimated from diatom biostratigraphy (see the "Expedition 311 summary" chapter; Akiba et al.) and decrease markedly from Sites U1325 and U1326 (>400 m/m.y.) to Site U1329 (<100 m/m.y.). Sedimentation rates in the Cascadia Basin seaward of the deformation front are even higher, reaching $\sim 1000 \mathrm{~m} / \mathrm{m} . \mathrm{y}$. at Site 888 , located $\sim 60 \mathrm{~km}$ south of the Expedition 311 transect (Westbrook, Carson, Musgrave, et al., 1994). However, note that Site U1329 is dominated by a marked unconformity at $\sim 136$ mbsf, where $\sim 5$ m.y. of sediments were eroded (a jump from 1.6 to 6.4 Ma was observed across the unconformity; Akiba et al.).

The presence of an advecting pore fluid from greater depth is also required to explain other observed inorganic pore water constituents, including iodine, bromine, and ammonia (Lu et al., 2008). The advection rates calculated by Lu et al. (2008) have very similar values to those modeled by Malinverno et al. (2008) and range from $0.015 \mathrm{~cm} / \mathrm{y}$ at Site U1325 to $0.06 \mathrm{~cm} / \mathrm{y}$ at Site U1326. All other sites have values of $\sim 0.03 \mathrm{~cm} / \mathrm{y}$. Additional modeling to achieve a better fit between the predicted and observed depth profiles of pore water halogen and ammonia constituents was also conducted by Lu et al. (2008) by incorporating lateral advection through fractures/faults.

Sites U1325 and U1326 show increasing pore water chlorinity/salinity with depth, whereas Sites U1327, U1328, and U1329 show (to various degrees) pore water freshening with depth. The observed increase in pore water chlorinity/salinity is attributed to diagenetic processes (e.g., through low-temperature reactions where volcanic ash is transformed to zeolite, releasing salt). Given that no information exists about the exact type zeolite involved in the actual reaction at depth and the possibilities of having generated zeolites from very low temperatures (as low as $5^{\circ} \mathrm{C}$ in the case of phillipsite), it is difficult to determine an exact depth range for this reaction. For example, diagenetic alteration of ash to zeolite was reported to occur from $200 \mathrm{~m}$ to $11 \mathrm{~km}$ below seafloor by Iijima and Utada (1966), but it likely occurs as soon as sediment is deposited (i.e., diagenetic alteration and related salt production happens throughout the entire sediment column).

The pore water freshening with depth was expected to be a margin-wide phenomenon and simply a function of distance from the deformation front based on results from Leg 204 (Kastner et al., 1995a; Torres et al., 2004). The source of freshwater was attributed to low-temperature clay dehydration processes (e.g., smectite-to-illite transformation) that typically occur over a temperature range of $60^{\circ}-$ $160^{\circ} \mathrm{C}$ (e.g., Bekins et al., 1994). With a temperature gradient of $\sim 60^{\circ} \mathrm{C} / \mathrm{km}$ at Site U1327, the source of this freshwater pool is at a depth of $~ 1000$ 2750 mbsf.

The clear separation between salt and freshwater sources along the margin remains a puzzle because the two assumed diagenetic reactions could occur over the same depth range. Furthermore, the distribution of volcanic ash and smectite should not be 
drastically different across the accretionary prism. Bartier et al. indicate only modest variation in the clay mineralogy among all of the sites, and ash layers have been reported at all sites, including Site 888 (Westbrook, Carson, Musgrave, et al., 1994; see the "Expedition 311 summary" chapter).

However, the apparent complex segregation of the margin from more saline to fresher formation waters can be explained by a relatively simple model that incorporates the change in fluid expulsion rates along the margin, as modeled by Hyndman and Davis (1992) (Fig. F8). The expulsion rate is expected to be at maximum $\sim 15 \mathrm{~km}$ landward of the deformation front, and little fluid is expelled along the transect until a distance of $\sim 10 \mathrm{~km}$. The pore water freshening reported in Figure F8 for Leg 204 and Expedition 311 sites was determined at a constant depth of $200 \mathrm{mbsf}$ and is all relative to seawater. Pore water freshening is seen only at sites $\sim 15 \mathrm{~km}$ east of the deformation front, and the freshening quickly increases landward. The slowdown of the modeled expulsion rate is reflected in the decrease in freshening between Sites U1327 (Site 889) and U1329; however, the erosion and associated drastic difference in sedimentology at Site U1329 may also be a factor.

Furthermore, at Sites U1325 and U1326, little water has been expelled from depth, and, because the source of any freshwater must come from greater depth ( 1000 mbsf), there is little mixing of the pore waters whose salt contents increased from the ashto-zeolite transformation. As soon as freshwater is expelled in large quantities, freshening overprints salt formation and the pore waters show an overall reduction in chlorinity. Additionally, the accretionary prism is relatively thin near the deformation front, which reduces the possible region for freshwater generation (which requires higher temperatures-i.e., a thicker sediment column). Thus, there is a relatively lesser amount of source material beneath Sites U1325 and U1326 compared to the more mature, thicker prism farther east beneath Site U1327 (Site 889) and others.

Additional constraints on the deep fluid sources come from lithium and strontium data (e.g., Teichert et al., 2005; Kastner et al., 1995b). Here we use the measured concentration-depth profiles of lithium and strontium as well as ${ }^{87} \mathrm{Sr} /{ }^{86} \mathrm{Sr}$ ratios (Fig. F9) to discern types of fluid sources that may have contributed to the pore water sampled along the Expedition 311 transect (M. Kastner and M. Torres, unpubl. data).

The mobility of lithium is temperature dependent. At lower temperatures, lithium is partitioned into clay minerals, whereas it is leached into the pore fluid at temperatures $>70^{\circ} \mathrm{C}$. At the thermal gradients measured during Expedition $311\left(\sim 60^{\circ} \mathrm{C} / \mathrm{km}\right)$, inferred in situ lithium leaching mainly occurs at depths $>1 \mathrm{~km}$ (see also Kastner et al., 1995b). Thus, higher-than-seawater lithium concentrations found at shallower depths are indicative of an upwardmigrating deep fluid source. Pore water lithium concentrations increase with depth at all sites (especially Sites U1327 and U1329) and with distance away from the deformation front along the transect (Fig. F9A). A shift to elevated lithium concentrations even at shallow depths of $<50$ mbsf was observed at Sites U1327 and U1329, which is in very good agreement with the previously stated evolution of fluid expulsion rates along the drilling transect. However, the cold vent Site U1328 surprisingly does not show much evidence for equivalent deeper fluid advection, although it is only $3.5 \mathrm{~km}$ south and about the same distance from the deformation front as Site U1327.

From strontium concentration and isotopic ratio data (Fig. F9B-F9C) it is apparent that the values at Site U1329 below the unconformity are the only anomalous values found along the Expedition 311 transect. It is also evident that the entire set of values from all sites is overprinted by diagenesis from carbonate precipitation (Fig. F9D), especially for Site U1327-a finding that was already noted by Kastner et al., (1995b) for nearby Site 889. Similar observations were made by Teichert et al. (2005) for data from Leg 204. Teichert et al. (2005) also proposed a mixing line (dotted black line in Fig. F9D) for the strontium isotope and concentration data for the southern Cascadia margin using seawater and bottom fluids collected from ODP Sites 1027 and 1026, similar to the previous mixing line proposed by Kastner et al. (1995b).

The strontium concentrations and isotopic ratios at all sites from all previous drilling (including Expedition 311, with the exception of Site U1329), can easily be explained by the mixing of seawater and the deep fluid source measured at Sites 1026 and 1027. The apparent end-member inferred for Site U1329 could be different (but basaltic in nature) from the incoming plate (M. Torres, pers. comm., 2008). On the other hand, the observation based on Leg 146 that the sites drilled from Northern Hydrate Ridge to offshore Vancouver Island communicate with the same deep fluid is striking (Kastner et al., 1995b), and it would make sense if Site U1329 also communicates with the same deep fluid. Thus, the observed local deviations at Site U1329 may indicate some mixing with pore fluids influenced by in situ reactions with certain more radiogenic detrital phases, though this is not necessarily the case for regional 
variations. This is further emphasized by the fact that the anomalous values were obtained only for samples from depths below the unconformity at Site U1329, where sediments older than 6.0 Ma were recovered, in contrast to all other sediments of mainly younger than 1.0 Ma age (Akiba et al.).

\section{Methane production from $\mathrm{CO}_{2}$ reduction and dissolved inorganic carbon isotopic composition}

The $\delta^{13} \mathrm{C}$ values of methane range from a minimum of $-82.2 \%$ near the deformation front at Site $\mathrm{U} 1326$ to a maximum of $-39.5 \%$ at the most landward location Site U1329 (Fig. F10A). The $\delta^{13} \mathrm{C}$ enrichment of methane has classically been interpreted as evidence for the transition from microbial to thermogenic methane. However, the associated $\mathrm{CO}_{2}$ sampled during Expedition 311 exhibits a similar trend of $\delta^{13} \mathrm{C}$ enrichment, with values ranging from $-22.5 \%$ to $+25.7 \%$ (Fig. F10A). The magnitude of the carbon isotope separation between methane and $\mathrm{CO}_{2}$ is consistent with the kinetic isotope effect (KIE) that occurs during microbially mediated carbonate reduction. Furthermore, the gaseous hydrocarbon content is composed of $>99.8 \%$ (by volume) methane and the methane has uniform $\delta \mathrm{D}_{\mathrm{CH} 4}$ values $(-172 \% \mathrm{oo} \% 8 \%$ ) that are also consistent with carbonate reduction. Little evidence was found of any thermogenic gas source along the transect, which is distinct from the thermogenic methane signatures seen at Barkley Canyon located $\sim 60 \mathrm{~km}$ southeast of the Expedition 311 transect sites (Pohlman et al., 2005). These combined results suggest that microbial $\mathrm{CO}_{2}$ reduction is the predominant source of the methane. The increase in $\delta^{13} \mathrm{C}$ with sediment depth at each site is a closedsystem KIE from preferential consumption of ${ }^{12} \mathrm{CO}_{2}$ during methanogenesis, which drives the residual $\mathrm{CO}_{2}$ and accumulated methane toward more enriched ${ }^{13} \mathrm{C}$ values. Similar observations were made at Blake Ridge (Leg 164; Paull et al., 2000) and SHR (Leg 204; Claypool et al., 2006). The trend of ${ }^{13} \mathrm{C}$ enrichment in DIC (Torres and Kastner) is similar to that of $\mathrm{CO}_{2}$, with the difference being related to equilibrium isotope effects that occur during the degassing of $\mathrm{CO}_{2}$ from the dissolved phase (Emrich et al., 1970). The $\delta^{13} \mathrm{C}$-DIC values are near $-5 \%$ at Cascadia Basin Site 888 and near $+32 \%$ for Site U1329 (Fig. F10B).

An additional explanation for the downcore increase in $\delta^{13} \mathrm{C}$ composition is the possibility of acetoclastic methanogenesis at Sites U1327 and U1329 (Heuer et al., 2007, 2009). Most often, acetate concentrations increase in the sediments from $<5 \mu \mathrm{M}$ at the sedi- ment/water interface to a maximum of $\sim 100 \mu \mathrm{M}$ at 250 mbsf. However, Site U1328 deviates from this relationship, where maximum values reach almost 800 $\mu \mathrm{M}$ at 250 mbsf. The $\delta^{13} \mathrm{C}$ values of acetate range from $-48 \%$ o to $-8 \%$. However, the largest enrichment of $\delta^{13} \mathrm{C}$ acetate (about -10\%o) occurs over the depth range from 130 to $220 \mathrm{mbsf}$ at Site U1327 (Heuer et al., 2007, 2009).

As noted by Pohlman et al. (2009), although the $\mathrm{CO}_{2}$ and methane profiles are influenced by closedsystem KIE, additional sources and sinks also affect the mass balance of $\mathrm{CO}_{2}$ and methane. A completely closed system would result in $\delta^{13} \mathrm{C}-\mathrm{CO}_{2}$ values that continually increase with depth, whereas the $\delta^{13} \mathrm{C}$ $\mathrm{CO}_{2}$ profiles at each site approach constant values with increasing depth. Constant $\delta^{13} \mathrm{C}$ values with increasing depth for $\mathrm{CO}_{2}$ and methane may be explained by mixing with a deeper isotopically uniform gas reservoir (Paull et al., 2000) or contributions from organic matter fermentation that balance losses to carbonate reduction (Claypool et al., 1985).

As mentioned before, the carbon isotopic composition of the residual DIC shows a general progressive enrichment with distance from the deformation front as well as downcore for all sites along the Expedition 311 transect, which can be explained by a KIE from preferential consumption of the lighter ${ }^{12} \mathrm{CO}_{2}$ during methanogenesis. However, Site U1326 shows a distinctively different depth profile compared to the other sites in that there are two intervals where $\delta^{13} \mathrm{C}$ values are ${ }^{13} \mathrm{C}$ depleted (Fig. F11). The upper anomalous interval (minimum $\delta^{13} \mathrm{C}$ is around $-4 \%$ Peedee belemnite [PDB]) extends from $\sim 40$ to $\sim 140 \mathrm{mbsf}$, with the top of the gas hydrate reported at $\sim 47$ mbsf. The maximum $\delta^{13} \mathrm{C}$ value of $+11 \%$ PDB is reached at $\sim 155$ mbsf before values decrease again to around $+4 \%$ PDB. This distinct pattern toward lighter carbon isotopic composition is a possible indicator of the influx of nondepleted pore water from depth.

\section{Regional in situ methane production and vent-associated gas migration}

The $\delta^{13} \mathrm{C}$ composition of the methane recovered from gas hydrate samples from 44 and $53 \mathrm{mbsf}$ at Site U1326 is identical to the composition of core void and sediment methane gas, which suggests that methane in the gas hydrate samples was formed in situ near the site of gas hydrate nucleation and was not derived from a deeper source that migrated into the GHSZ (Pohlman et al., 2006). This contrasts with observations made at the cold vent at Site U1328. The cold vent is characterized by a cap of gas hydrate-rich sediments that extends to $\sim 40 \mathrm{mbsf}$ (see 
the "Site U1328" chapter). The depth profiles of $\delta^{13} \mathrm{C}$ composition of core void and sediment methane gas at Site U1328 are similar to those seen at the other sites along the transect. Values gradually decrease from around $-62 \%$ PDB at 300 mbsf to about $-72 \%$ PDB at the seafloor. However, within the uppermost $50 \mathrm{mbsf}$ there is a secondary trend of increasing $\delta^{13} \mathrm{C}$ composition to values similar to those observed at the bottom of the hole. Gas hydrate samples recovered within the depth interval where the core gas methane was ${ }^{13} \mathrm{C}$ enriched have similar values, suggesting that the gas hydrate-bound gas and dissolved gas in that interval are derived from a deep-migrated source (Pohlman et al., 2006).

The main source of methane in gas hydrates sampled during Expedition 311 is $\mathrm{CO}_{2}$ reduction, which raises a key question: What are the production rates? Several microbiological experiments were conducted to determine the rate of methane production from Expedition 311 sediments (Yoshioka et al., 2010) and Leg 204 (Colwell et al., 2008). However, accurate in situ microbial methane production rates are difficult to determine using incubation experiments, which often result in unrealistically high production rates (Colwell et al., 2008). Nevertheless, methane production rates at Sites U1327 and U1329 were determined to be on average $\sim 1 \mathrm{pmol} / \mathrm{cm}^{3} /$ day, with highly variable rates with depth (Yoshioka et al., 2010). The value of $\sim 1 \mathrm{pmol} / \mathrm{cm}^{3} /$ day is comparable to values obtained by Colwell et al. (2008), who reported a rate of $0.017 \mathrm{fmol} /$ cell/day using an average cell count of $\sim 1000$ cells $/ \mathrm{g}$ and a density of $\sim 1.7 \mathrm{~g} / \mathrm{cm}^{3}$. Another independent estimate of methane production can be obtained from the progressive enrichment of the $\delta^{13} \mathrm{C}$ composition of residual DIC (Torres et al., 2007) which yields results similar to estimates made by Colwell et al. (2008).

Yoshioka et al. (2010) determined that methane production at Site U1327 is higher within the depth interval where gas hydrate is inferred to occur than in the near-surface, gas hydrate-free sediments or the sediments below the BSR. They also show that at Site U1327 methanogens are more abundant in the gas hydrate-bearing sediments than in sediments at other depths. In contrast, at Site U1329 there is no evidence for a substantial amount of gas hydrate in the sediments. Methane production rates at this site are also relatively high in the sediments between 70 and 140 mbsf (comparable to those at Site U1327). This suggests that the enhancement of methane production rates in the hydrate-bearing interval at Site U1327 is likely unrelated to the actual occurrence and distribution of gas hydrate but instead may be related to the location of the site within the accretionary prism or sediment composition (high methane production rates were only seen in accreted sediments below $100 \mathrm{mbsf}$ ).

\section{A modified model of fluid expulsion and gas hydrate formation on the northern Cascadia margin}

The combined scientific results from Expedition 311 allow us to modify the earlier fluid expulsion model proposed by Hyndman and Davis (1992). A conceptual diagram incorporating the main features of this revised model is shown in Figure F12. As in the earlier model, pervasive fluid expulsion as a result of tectonic thickening and shortening of the sediment package within the accreted wedge is required to explain the observations. The margin is characterized by nonuniform fluid expulsion rates, which result in the evolution of different fluid sources in the uppermost few hundred meters below seafloor along the margin. At Sites U1326 and U1325 (within the first $10 \mathrm{~km}$ from the deformation front), salt generation from the ash-to-zeolite transformation dominates. In contrast, fresher pore fluids are observed farther from the deformation front (Sites U1327 and U1328) as a result of deeper rooted smectite-to-illite transformation and freshwater expulsion that becomes more prevalent landward (especially 15-20 km away from the deformation front). However, farther landward, the fluid expulsion rate decreases and the amount of freshening in the pore fluid is reduced (as seen at Site U1329). Data from Site U1329 may also indicate communication with a different (and likely more landward) fluid source of basaltic origin (other than the downgoing crust). However, the data are nonconclusive and the issue is further complicated by the presence of a pronounced unconformity, where a $5 \mathrm{~m} . \mathrm{y}$. long record of sediments is missing.

With the exception of the cold seep Site U1328, methane is produced predominantly in situ within the GHSZ. Microbes utilize organic matter (deposited either by pelagic or turbidite sedimentation) to produce methane that is consequently incorporated into gas hydrate. Continuous sedimentation and associated burial, as well as lateral transport during accretionary prism formation, result in the enrichment of the $\delta^{13} \mathrm{C}$ composition of $\mathrm{CH}_{4}$ with distance from the deformation front and with depth at each site along the Expedition 311 transect as the organic matter is progressively degraded landward as well as with depth.

The preference for gas hydrate occurrence in coarser grained sediments has been observed at many marine (Collett et al., 2008; Weinberger et al., 2005; 
Kimura, Silver, Blum, et al., 1997; Ginsberg et al., 2000) and terrestrial (Dallimore et al., 1999; Boswell et al., 2008) locations and in laboratory experiments (e.g., Tohidi et al., 2001; Uchida et al., 1999). The separation of high gas hydrate concentrations within the sandier turbidite sequences and low to absent gas hydrate concentrations within the finer grained sediments without any evidence for an underlying gas migration component can be explained by the model of Malinverno (2010), in which gas is microbially generated in the finer grained sediments and then transported by diffusion into the sandier sediments, where it accumulates to saturations in excess of local solubility.

Although these models and associated geochemical and isotopic data show that in situ methane production from carbonate reduction is the main source of methane and is sufficient to explain all observations of gas hydrate distribution, concentration, and mode of occurrence along the Expedition 311 transect, the advection of methane is still a requirement in the overall formation of gas hydrate within the accretionary prism. If in situ methane production (peaking near the sulfate-methane transition zone and then exponentially decreasing with depth) is the sole source for gas hydrate formation, gas hydrate should also be abundant in the sediments of the abyssal plain as the total organic carbon content at Site 888 (average $=0.54 \mathrm{wt} \%$; Cragg et al., 1996) is relatively similar to that at all other sites along the Expedition 311 transect $(\mathrm{U} 1325=0.52 \mathrm{wt} \%, \mathrm{U} 1326=0.42 \mathrm{wt} \%$, $\mathrm{U} 1327=0.7 \mathrm{wt} \%, \mathrm{U} 1329=0.61 \mathrm{wt} \%$, and $\mathrm{U} 1328=$ 0.5 wt\%; data from Kim and Lee). However, logging and coring at Site 888 did not show any evidence of gas hydrate.

Fluid advection is observed and constrained by concentration gradients of multiple pore water constituents (e.g., $\mathrm{Cl}, \mathrm{Br}, \mathrm{Li}$, and $\mathrm{Sr}$ ), and fluid sources can be relatively deep $(\sim 1 \mathrm{~km})$. Dissolved methane can also be transported by these advecting fluids; however, the depth of the methane does not necessarily have to be deep, and migration pathways can be relatively short (i.e., entirely within the gas hydrate occurrence zone). Continuous recycling of gas hydrate and free gas is occurring at the BGHSZ because of the active tectonic deformation of the accretionary prism, combined with rapid sedimentation and mass wasting processes. The characteristic downhole isotopic signature of the dissolved methane can result from the mixing of "freshly" produced methane by in situ bacterial processes and some "older" methane advected from below.

The vertical and lateral extent of the local gas hydrate occurrence is governed through temperature and pressure, local rates in fluid advection and sedimentation, and the abundance of organic matter and microbes, as well as by appropriate host sediment (sand). Thus, a rather heterogeneous picture of gas hydrate occurrence is derived with a high degree of variability on the kilometer scale from site to site along the Expedition 311 transect, on the 10-100 meter scale between adjacent holes at one site, and on the meter to submeter scale vertically within each hole. Focused fluid flow along faults can generate cold vents with massive gas hydrate formation near the seafloor, as seen at Site U1328. Methane in the shallow ( $<40 \mathrm{mbsf})$ gas hydrate accumulation at the cold vent is transported from greater depth. A model of cold vent-related fluid flow and gas hydrate formation was previously published by Riedel et al. (2006). In this model, methane-rich pore fluid and/ or free methane gas is passed through the sediment column along a series of filamentous fractures. As methane solubility drastically decreases near the seafloor, massive gas hydrate is formed and excess methane is vented into the overlying ocean. The result is the formation of a massive gas hydrate cap and widespread seafloor carbonate formations and chemosynthetic communities.

The BGHSZ (seismically defined as a BSR) is a temporal trap for some amounts of free gas below, which gives rise to the seismic velocity decrease across the interface. Because there appears to be only little migration of free gas from greater depths on a regional scale, the free gas trapped below the BGHSZ could best be explained as being derived from gas hydrate recycling. The combination of continuous sedimentation processes and tectonic uplift with relatively rapid fluid migration (subsaturated in methane) results in the recycling of gas hydrate at the BGHSZ and the accumulation of a thin free gas zone as described by Haacke et al. (2007).

\section{Summary}

The combined results of studies carried out during and in conjunction with Expedition 311 reveal a very complex sedimentological, geochemical, and geophysical regime that controls the formation and distribution of gas hydrate on the northern Cascadia margin. Results from Expedition 311 have significantly augmented our understanding of the geologic controls on the occurrence of gas hydrate. The main conclusions that can be drawn from the studies associated with Expedition 311 are as follows:

1. Methane within sediment and recovered gas hydrate along the expedition transect were produced primarily by microbial $\mathrm{CO}_{2}$ reduction and 
secondarily by acetate fermentation; all hydrocarbon sources are microbial, and no thermogenic gases were detected.

2. Isotope fractionation during microbial generation of methane results in a progressive isotopic enrichment of the carbon in the methane, $\mathrm{CO}_{2}$, and DIC with increasing sediment depth and distance from the deformation front.

3. Pore fluid composition (e.g., chlorinity) demonstrates a significant component of pervasive upward fluid migration across the accretionary complex.

4. Fluid expulsion is nonuniform across the margin, with expulsion rates being highest $\sim 15 \mathrm{~km}$ away from the deformation front. The systematic change in expulsion rates is the main cause of the apparent separation into saltier and fresher pore fluids at depth because it controls the amount of upward-migrating fresher pore fluids that mix with those pore waters affected by salt-generating diagenetic processes.

5. Diffuse upward pore fluid migration is likely overprinted by flow through conduits such as fractures, faults, or permeable strata.

6. Evidence for a deep-migrated source of methane was observed in shallow ( $<50 \mathrm{mbsf})$ gas hydrate accumulations at the cold vent Site U1328 (Bullseye vent), where near-vertical fracture systems delivered methane from a deep source to the surface.

7. Some component of regional dissolved methane advection through the GHSZ is required to explain the presence of gas hydrate occurrence within the accretionary prism and not within the abyssal plain sediments. This advection, in combination with methane production and sedimentation rates, defines the overall thickness of the gas hydrate occurrence zone.

8. Gas hydrate occurs preferentially in coarser grained sediments (sandy/silty turbidites) and is mainly formed from methane produced in situ.

9. Gas hydrate concentrations in the pore space of the sediments are low $(<5 \%)$ when averaged over the entire gas hydrate occurrence zone. However, locally, gas hydrate concentrations within sand layers can be as high as 50\% of the pore space.

10. Gas hydrate distribution is highly heterogeneous across the margin at all scales between each site visited as well at each site between adjacent boreholes, making remote gas hydrate detection and quantification challenging.

11. Gas hydrate occurs anywhere within the gas hydrate stability zone where favorable conditions occur (sufficient gas concentration above local solubility and the presence of coarse-grained sediments) and not preferably right above the BSR, as previously predicted (Hyndman and Davis, 1992; Hyndman et al., 2001).

12.The top of gas hydrate occurrence along the expedition transect (and the overall thickness of gas hydrate occurrence) deepens with distance from the deformation front, likely as a result of a progressive decrease in pore fluid advection and/or decreasing organic matter quality.

\section{Acknowledgments}

Samples and data were provided by the Integrated Ocean Drilling Program (IODP), which is funded by the U.S. National Science Foundation and participating countries under management of IODP Management International, Inc. We thank the captain and crew of the R/V JOIDES Resolution and the technical staff for their support at sea. Additional thanks goes to the onboard and postcruise scientific community, whose research results were synthesized in this paper. Other data collected from IODP Expedition 311 samples but not reviewed in this synthesis can be found in data reports by Bahr et al., Hester et al., Wortman, Blanc-Valleron et al., and Pierre et al.

\section{References}

Archie, G.E., 1942. The electrical resistivity log as an aid in determining some reservoir characteristics. Trans. Am. Inst. Min., Metall. Pet. Eng., 146:54-62.

Bekins, B., McCaffrey, A.M., and Dreiss, S.J., 1994. Influence of kinetics on the smectite to illite transition in the Barbados accretionary prism. J. Geophys. Res., [Solid Earth], 99(B9):18147-18158. doi:10.1029/94JB01187

Bekins, B.A., and Dreiss, S.J., 1992. A simplified analysis of parameters controlling dewatering in accretionary prisms. Earth Planet. Sci. Lett., 10(3-4)9:275-287. doi:10.1016/0012-821X(92)90092-A

Borowski, W.S., Paull, C.K., and Ussler, W., III, 1996. Marine pore-water sulfate profiles indicate in situ methane flux from underlying gas hydrate. Geology, 24(7):655-658. doi:10.1130/0091-

7613(1996)024<0655:MPWSPI>2.3.CO;2

Boswell, R., Hunter, R., Collett, T.S., Digert, S., Hancock, S.H., Weeks, M., and the Mount Elbert Science Team, 2008. Investigation of gas hydrate-bearing sandstone reservoirs at the "Mount Elbert" stratigraphic test well, Milne Point, Alaska. Proc. Int. Conf. Gas Hydrates, 6. https://circle.ubc.ca/handle/2429/1167

Chapman, N.R., Gettrust, J.F., Walia, R., Hannay, D., Spence, G.D., Wood, W.T., and Hyndman, R.D., 2002. High-resolution, deep-towed, multichannel seismic survey of deep-sea gas hydrates off western Canada. Geophysics, 67(4):1038-1047. doi:10.1190/1.1500364

Chen, M.-A.P., 2006. Northern Cascadia marine gas hydrate: constraints from resistivity, velocity, and AVO [M.S. thesis]. Univ. Victoria, British Columbia. 
Claypool, G.E., Milkov, A.V., Lee, Y.-J., Torres, M.E., Borowski, W.S., and Tomaru, H., 2006. Microbial methane generation and gas transport in shallow sediments of an accretionary complex, southern Hydrate Ridge (ODP Leg 204), offshore Oregon, USA. In Tréhu, A.M., Bohrmann, G., Torres, M.E., and Colwell, F.S. (Eds.), Proc. ODP, Sci. Results, 204: College Station, TX (Ocean Drilling Program), 1-52. doi:10.2973/ odp.proc.sr.204.113.2006

Claypool, G.E., Threlkeld, C.N., Mankiewicz, P.N., Arthur, M.A., and Anderson, F.T., 1985. Isotopic composition of interstitial fluids and origin of methane in slope sediment of the Middle America Trench, Deep Sea Drilling Project Leg 84. In von Huene, R., Aubouin, J., et al., Init. Repts. DSDP, 84: Washington (U.S. Govt. Printing Office), 683-691. doi:10.2973/dsdp.proc.84.124.1985

Collett, T.S., and Ladd, J., 2000. Detection of gas hydrate with downhole logs and assessment of gas hydrate concentrations (saturations) and gas volumes on the Blake Ridge with electrical resistivity log data. In Paull, C.K., Matsumoto, R., Wallace, P.J., and Dillon, W.P. (Eds.), Proc. ODP, Sci. Results, 164: College Station, TX (Ocean Drilling Program), 179-191. doi:10.2973/

odp.proc.sr.164.219.2000

Collett, T.S., Riedel, M., Cochran, J., Boswell, R., Presley, J., Kumar, P., Sathe, A.V., Sethi, A., Lall, M., Sibal, V., and the NGHP Expedition 01 Scientists, 2008. Indian National Gas Hydrate Program (NGHP) Expedition 01, Initial Report: India (DGH, Ministry of Petroleum and Natural Gas).

Colwell, F.S., Boyd, S., Delwiche, M.E., Reed, D.W., Phelps, T.J., and Newby, D.T., 2008. Estimates of biogenic methane production rates in deep marine sediments at Hydrate Ridge, Cascadia margin. Appl. Environ. Microbiol., 74(11):3444-3452. doi:10.1128/AEM.02114-07

Cragg, B.A., Parkes, R.J., Fry, J.C., Weightman, A.J., Rochelle, P.A., and Maxwell, J.R., 1996. Bacterial populations and processes in sediments containing gas hydrates (ODP Leg 146: Cascadia margin). Earth Planet. Sci. Lett., 139(3-4):497-507. doi:10.1016/0012821X(95)00246-9

Dallimore, S.R., Uchida, T., and Collett, T.S. (Eds.), 1999. Scientific Results from JAPEX/JNOC/GSC Mallik 2L-38 Gas Hydrate Research Well, MacKenzie Delta, Northwest Territories, Canada. Bull.-Geol. Surv. Can, 544.

Dickens, G.R., Paull, C.K., and Wallace, P., 1997. Direct measurement of in situ methane quantities in a large gas-hydrate reservoir. Nature (London, U. K.), 385(6615):426-428. doi:10.1038/385426a0

Dickens, G.R., and Snyder, G.T., 2009. Interpreting upward methane flux from marine pore water profiles. Fire Ice, Winter 2009:7-10.

Ellis, M., Minshull, T., Sinha, M., and Best, A., 2008. Joint electrical and seismic interpretation of gas hydrate bearing sediments from the Cascadia margin. Eos, Trans. Am. Geophys. Union, 89(53)(Suppl.):OS43F-02. (Abstract) http://www.agu.org/meetings/fm08/waisfm08.html

Emrich, K., Ehhalt, D., and Vogel, J.C., 1970. Carbon isotope fractionation during the precipitation of calcium carbonate. Earth Planet. Sci. Lett., 8(5):363-371.

doi:10.1016/0012-821X(70)90109-3

Flemings, P.B., Liu, X., and Winters, W.J., 2003. Critical pressure and multiphase flow in Blake Ridge gas hydrates. Geology, 31(12):1057-1060. doi:10.1130/ G19863.1

Ginsburg, G., Soloviev, V., Matveeva, T., and Andreeva, I., 2000. Sediment grain-size control on gas hydrate presence, Sites 994, 995, and 997. In Paull, C.K., Matsumoto, R., Wallace, P.J., and Dillon, W.P. (Eds.), Proc. ODP, Sci. Results, 164: College Station, TX (Ocean Drilling Program), 237-245. doi:10.2973/ odp.proc.sr.164.236.2000

Goldberg, D., Guerin, G., Malinverno, A., and Cook, A., 2008. Velocity analysis of LWD and wireline sonic data in hydrate-bearing sediments on the Cascadia margin. Proc. Int. Conf. Gas Hydrates, 6. https://circle.ubc.ca/ handle/2429/1619

Haacke, R.R., Westbrook, G.K., and Hyndman, R.D., 2007. Gas hydrate, fluid flow and free gas: formation of the bottom-simulating reflector. Earth Planet. Sci. Lett., 261(3-4):407-420. doi:10.1016/j.epsl.2007.07.008

Heuer, V., Pohlman, J., Elvert, M., and Hinrichs, K.-U., 2007. Carbon isotopic compositions of acetate as proxies for biogeochemical processes in gas hydrate bearing sediments. Abstracts of the 17th Annual V. M. Goldschmidt Conference. Geochim. Cosmochim. Acta, 71(15S):A402. http://goldschmidt.info/2007/ abstracts/A402.pdf

Heuer, V.B., Pohlman, J.W., Torres, M.E., Elvert M., and Hinrichs, K.-U., 2009. The stable carbon isotope biogeochemistry of acetate and other dissolved carbon species in deep subseafloor sediments at the northern Cascadia margin. Geochim. Cosmochim. Acta, 73:3323-3336. doi:10.1016/j.gca.2009.03.001

Hyndman, R.D., and Davis, E.E., 1992. A mechanism for the formation of methane hydrate and seafloor bottomsimulating reflectors by vertical fluid expulsion. J. Geophys. Res., [Solid Earth], 97(B5):7025-7041. doi:10.1029/ 91JB03061

Hyndman, R.D., Spence, G.D., Chapman, R., Riedel, M., and Edwards, R.N., 2001. Geophysical studies of marine gas hydrate in northern Cascadia. In Paull, C.K., and Dillon, W.P. (Eds.), Natural Gas Hydrates: Occurrence, Distribution, and Detection. Geophys. Monogr., 124:273295.

Hyndman, R.D., Yuan, T., and Moran, K., 1999. The concentration of deep sea gas hydrates from downhole electrical resistivity logs and laboratory data. Earth Planet. Sci. Lett., 172(1-2):167-177. doi:10.1016/S0012821X(99)00192-2

Iijima, A., and Utada, M., 1966. Zeolites in sedimentary rocks, with references to the depositional environments and zonal distribution. Sedimentology, 7(4):327-357. doi:10.1111/j.1365-3091.1966.tb01299.x

Kastner, M., Kvenvolden, K.A., Whiticar, M.J., Camerlenghi, A., and Lorenson, T.D., 1995a. Relation between pore fluid chemistry and gas hydrates associated with bottom-simulating reflectors at the Cascadia margin, Sites 889 and 892. In Carson, B., Westbrook, G.K., Mus- 
grave, R.J., and Suess, E. (Eds.), Proc. ODP, Sci. Results, 146 (Pt. 1): College Station, TX (Ocean Drilling Program), 175-187. doi:10.2973/odp.proc.sr.1461.213.1995

Kastner, M., Sample, J.C., Whiticar, M.J., Hovland, M., Cragg, B.A., and Parkes, J.R., 1995b. Geochemical evidence for fluid flow and diagenesis at the Cascadia convergent margin. In Carson, B., Westbrook, G.K., Musgrave, R.J., and Suess, E. (Eds.), Proc. ODP, Sci. Results, 146 (Pt. 1): College Station, TX (Ocean Drilling Program), 375-384. doi:10.2973/odp.proc.sr.1461.243.1995

Kastner, M., Torres, M., Solomon, E., and Spivack, A.J., 2008. Marine pore fluid profiles of dissolved sulfate; do they reflect in situ methane fluxes? Fire Ice, Summer 2008:6-8.

Kimura, G., Silver, E.A., Blum, P., et al., 1997. Proc. ODP, Init. Repts., 170: College Station, TX (Ocean Drilling Program). doi:10.2973/odp.proc.ir.170.1997

Lu, Z., Hensen, C., Fehn, U., and Wallmann, K., 2008. Halogen and ${ }^{129} \mathrm{I}$ systematics in gas hydrate fields at the northern Cascadia margin (IODP Expedition 311): insights from numerical modeling. Geochem., Geophys., Geosyst., 9(10):Q10006. doi:10.1029/2008GC002156

Malinverno, A., 2010. Marine gas hydrates in thin sand layers that soak up microbial methane. Earth Planet. Sci. Lett., 292(3-4):399-408. doi:10.1016/ j.epsl.2010.02.008

Malinverno, A., Kastner, M., Torres, M.E., and Wortmann, U.G., 2008. Gas hydrate occurrence from pore water chlorinity and downhole logs in a transect across the northern Cascadia margin (Integrated Ocean Drilling Program Expedition 311). J. Geophys. Res., [Solid Earth], 113(B8):B08103. doi:10.1029/2008JB005702

Milkov, A.V., Dickens, G.R., Claypool, G.E., Lee, Y-J., Borowski, W.S., Torres, M.E., Xu, W., Tomaru, H., Tréhu, A.M., and Schultheiss, P., 2004. Co-existence of gas hydrate, free gas, and brine within the regional gas hydrate stability zone at Hydrate Ridge (Oregon margin): evidence from prolonged degassing of a pressurized core. Earth Planet. Sci. Lett., 222(3-4):829-843. doi:10.1016/j.epsl.2004.03.028

Paull, C.K., Lorensen, T.D., Borowski, W.S., Ussler, W., III, Olsen, K., and Rodriguez, N.M., 2000. Isotopic composition of $\mathrm{CH}_{4}, \mathrm{CO}_{2}$ species, and sedimentary organic matter within samples from the Blake Ridge: gas source implications. In Paull, C.K., Matsumoto, R., Wallace, P.J., and Dillon, W.P. (Eds.), Proc. ODP, Sci. Results, 164: College Station, TX (Ocean Drilling Program), 67-78. doi:10.2973/odp.proc.sr.164.207.2000

Paull, C.K., and Ussler, W., III, 1997. Are low salinity anomalies below BSRs a consequence of interstitial gas bubble barriers? Eos, Trans. Am. Geophys. Union, 78(46):F339. (Abstract)

Pohlman, J.W., Canuel, E.A., Chapman, N.R., Spence, G.D., Whiticar, M.J., and Coffin, R.B., 2005. The origin of thermogenic gas hydrates on the northern Cascadia margin as inferred from isotopic $\left({ }^{13} \mathrm{C} /{ }^{12} \mathrm{C}\right.$ and $\left.\mathrm{D} / \mathrm{H}\right)$ and molecular composition of hydrate and vent gas. Org.
Geochem., 36(5):703-716. doi:10.1016/j.orggeochem.2005.01.011

Pohlman, J.W., Kaneko, M., Heuer. V., Plummer, R., Coffin, R.B., and the IODP Expedition 311 Scientific Party, 2006. Molecular and isotopic characterization of gases from IODP Expedition 311: source and gas hydrate related controls. Eos, Trans. Am. Geophys. Union, 87(52)(Suppl.):OS11E-06. (Abstract). http:// www.agu.org/meetings/fm06/waisfm06.html

Pohlman, J.W., Kaneko, M., Heuer, V.B., Coffin, R.B., and Whiticar, M., 2009. Methane sources and production in the northern Cascadia margin gas hydrate system. Earth Planet. Sci. Lett., 287(3-4):504-512. doi:10.1016/ j.epsl.2009.08.037

Riedel, M., Spence, G.D., Chapman, N.R., and Hyndman, R.D., 2002. Seismic investigations of a vent field associated with gas hydrates, offshore Vancouver Island. $J$. Geophys. Res., 107(B9):2200. doi:10.1029/ 2001JB000269

Riedel, M., Novosel, I., Spence, G.D., Hyndman, R.D., Chapman, N.R., Solem, R.C., and Lewis, T., 2006. Geophysical and geochemical signatures associated with gas hydrate-related venting in the northern Cascadia margin. Geol. Soc. Am. Bull., 118(1):23-38. doi:10.1130/ B25720.1

Schowalter, T.T., 1979. Mechanics of secondary hydrocarbon migration and entrapment. AAPG Bull., 63(5):723760.

Suess, E., Torres, M.E., Bohrmann, G., Collier, R.W., Greinert, J., Linke, P., Rehder, G., Tréhu, A., Wallmann, K., Winckler, G., and Zuleger, E., 1999. Gas hydrate destabilization: enhanced dewatering, benthic material turnover and large methane plumes at the Cascadia convergent margin. Earth Planet. Sci. Lett.,170(1-2):115. doi:10.1016/S0012-821X(99)00092-8

Teichert, B.M.A., Torres, M.E., Bohrmann, G., and Eisenhauer, A., 2005. Fluid sources, fluid pathways and diagenetic reactions across an accretionary prism revealed by Sr and B geochemistry. Earth Planet. Sci. Lett., 239(12):106-121. doi:10.1016/j.epsl.2005.08.002

Tohidi, B., Anderson, R., Clennell, M.B., Burgass, R.W., and Biderkab, A.B., 2001. Visual observation of gas-hydrate formation and dissociation in synthetic porous media by means of glass micromodels. Geology, 29(9):867-870. doi:10.1130/00917613(2001)029<0867:VOOGHF>2.0.CO;2

Torres, M.E., Kastner, M., Wortmann, U.G., Colwell, F., and Kim, J., 2007. Estimates of methane production rates based on $\delta^{13} \mathrm{C}$ of the residual DIC in pore fluids from the Cascadia margin. Eos, Trans. Am. Geophys. Union, 88(52)(Suppl.):GC14A-04. (Abstract) http:// www.agu.org/meetings/fm07/waisfm07.html

Torres, M.E., Teichert, B.M.A., Tréhu, A.M., Borowski, W., and Tomaru, H., 2004. Relationship of pore water freshening to accretionary processes in the Cascadia margin: fluid sources and gas hydrate abundance. Geophys. Res. Lett., 31:L22305. doi:10.1029/2004GL021219

Torres, M.E., Tréhu, A.M., Cespedes, N., Kastner, M., Wortmann, U.G., Kim, J.-H., Long, P., Malinverno, A., Pohlman, J.W., Riedel, M., and Collett, T., 2008. Methane 
hydrate formation in turbidite sediments of northern Cascadia, IODP Expedition 311. Earth Planet. Sci. Lett., 271(1-4):170-180. doi:10.1016/j.epsl.2008.03.061

Tréhu, A.M., Bohrmann, G., Rack, F.R., Torres, M.E., et al., 2003. Proc. ODP, Init. Repts., 204: College Station, TX (Ocean Drilling Program). doi:10.2973/ odp.proc.ir.204.2003

Uchida, T., Ebinuma, T., and Ishizaki, T., 1999. Dissociation condition measurements of methane hydrate in confined small pores of porous glass. J. Phys. Chem. B, 103(18):3659-3662. doi:10.1021/jp9845591

von Huene, R., and Pecher, I.A., 1998. Vertical tectonics and the origins of BSRs along the Peru margin. Earth Planet Sci. Lett., 166(1-2):47-55. doi:10.1016/S0012821X(98)00274-X

Wang, J., 2006. The lithological constraint to gas hydrate formation: evidence of grain size of sediments from IODP 311 on Cascadia margin. Eos, Trans. Am. Geophys. Union, 87(52)(Suppl.):OS33B-1708 (Abstract). http:// www.agu.org/meetings/fm06/waisfm06.html

Wang, K., Hyndman, R.D., and Davis, E.E., 1993. Thermal effects of sediment thickening and fluid expulsion in accretionary prisms: model and parameter analysis. $J$. Geophys. Res., [Solid Earth], 98(B6):9975-9984. doi:10.1029/93JB00506

Weinberger, J.L., Brown, K.M., and Long, P.E., 2005. Painting a picture of gas hydrate distribution with thermal images. Geophys. Res. Lett., 32(4):L04609. doi:10.1029/ 2004 GL021437

Westbrook, G.K., Carson, B., Musgrave, R.J., et al., 1994. Proc. ODP, Init. Repts., 146 (Pt. 1): College Station, TX (Ocean Drilling Program). doi:10.2973/

odp.proc.ir.146-1.1994
Wortmann, U.G., Chernyavsky, B.M., Torres, M.E., and Kastner, M., 2008. ${ }^{34} \mathrm{~S} /{ }^{32} \mathrm{~S}$ and ${ }^{18} \mathrm{O} /{ }^{16} \mathrm{O}$ ratios of dissolved sulfate from interstitial water samples above gas hydrate bearing sediments of IODP Expedition 311, Cascadia. Eos, Trans. Am. Geophys. Union, 89(53)(Suppl.):OS33A1308. (Abstract) http://www.agu.org/meetings/fm08/ waisfm08.html

Xu, W., and Ruppel, C., 1999. Predicting the occurrence, distribution, and evolution of methane gas hydrate in porous marine sediments. J. Geophys. Res., [Solid Earth], 104(B3):5081-5096. doi:10.1029/1998JB900092

Yoshioka, H., Maruyama, A., Nakamura, T., Higashi, Y., Fuse, H., Sakata, S., and Bartlett, D.H., 2010. Activities and distribution of methanogenic and methane-oxidizing microbes in marine sediments from the Cascadia margin. Geobiology, 8(3):223-233. doi:10.1111/j.14724669.2009.00231.x

Yuan, T., Hyndman, R.D., Spence, G.D., and Desmons, B., 1996. Seismic velocity increase and deep-sea gas hydrate concentration above a bottom-simulating reflector on the northern Cascadia continental slope. J. Geophys. Res., [Solid Earth], 101(B6):13655-13671. doi:10.1029/ 96JB00102

Yuan, T., Spence, G.D., Hyndman, R.D., Minshull, T.A., and Singh, S.C., 1999. Seismic velocity studies of a gas hydrate bottom-simulating reflector on the northern Cascadia continental margin: amplitude modeling and full waveform inversion. J. Geophys. Res., [Solid Earth], 104(B1):1179-1192. doi:10.1029/1998JB900020

Initial receipt: 23 August 2009

Acceptance: 11 May 2010

Publication: 9 July 2010

MS 311-213 
Figure F1. Map of the Cascadia continental margin. Shown are the research sites established by Ocean Drilling Program (ODP) Legs 146 and 204 and Integrated Ocean Drilling Program (IODP) Expedition 311. The inset shows the inferred regional distribution of gas hydrate along the northern Cascadia margin (shaded area) from the occurrence of a bottom-simulating reflector as well as the general plate-tectonic regime of the northern Cascadia subduction zone (after Hyndman et al., 2001).

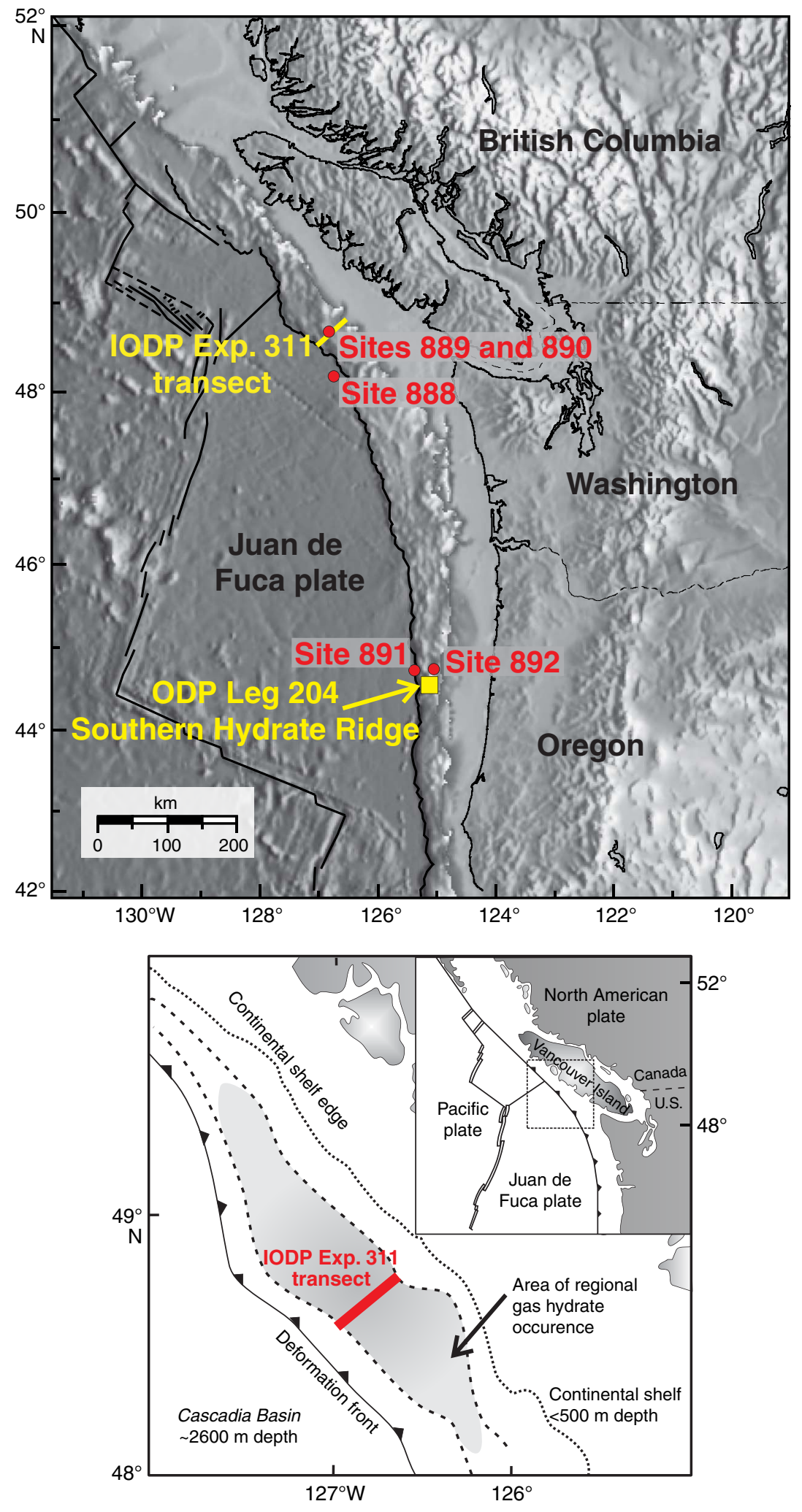


Figure F2. Seismic Line 89-08 from the ODP Leg 146 presite survey covering the Expedition 311 drill sites (U1326-U1329). ODP Site 888 is projected onto this line but is located $\sim 55 \mathrm{~km}$ to the southeast. Note that Site CAS-04B has not yet been established but is proposed as part of IODP Proposal 553-Full2. BSR = bottomsimulating reflector.

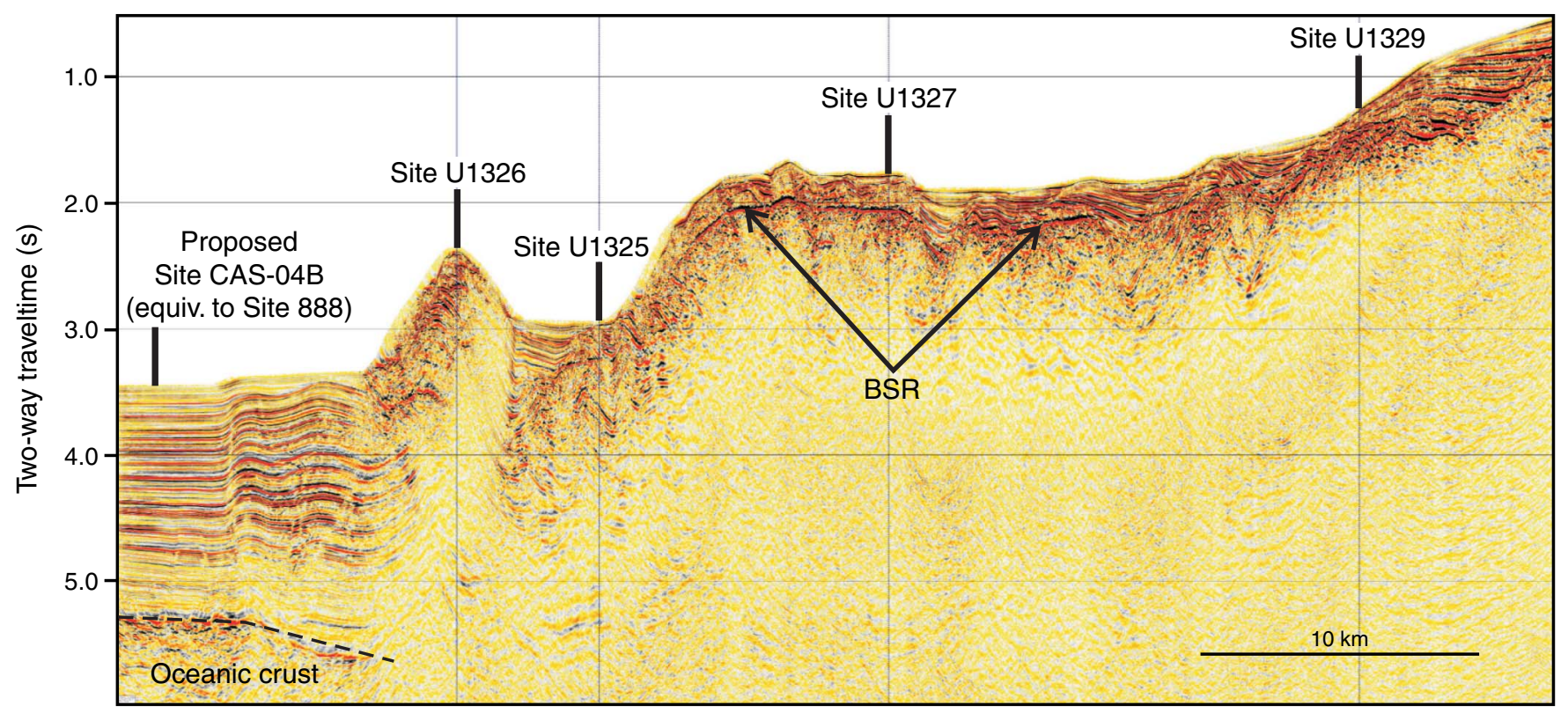


Figure F3. Compilation of all downhole temperature measurements conducted during IODP Expedition 311 compared to results obtained from ODP Leg 146, Site 889.

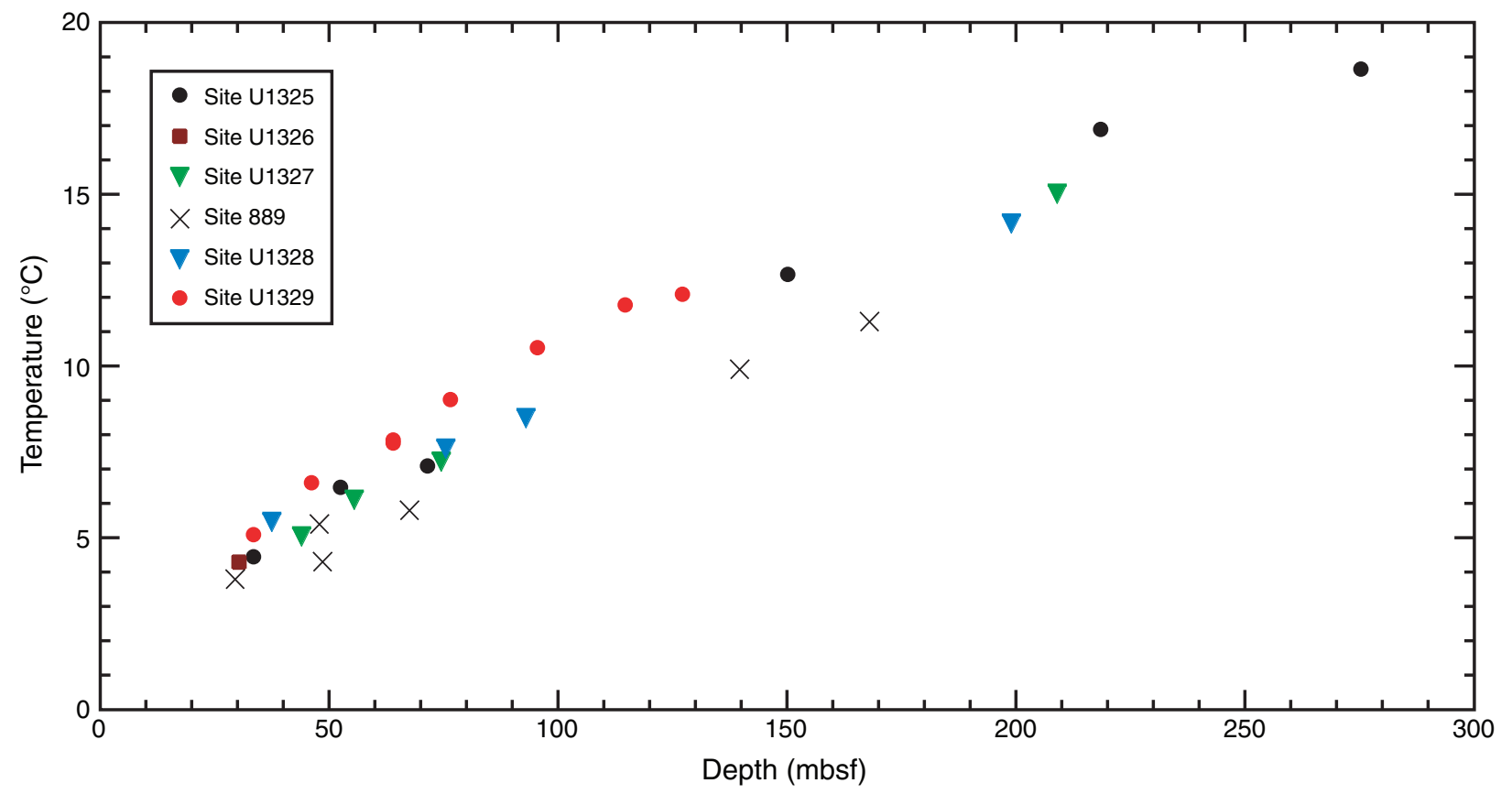


Figure F4. Compilation of all data points of methane concentration derived from pressure core degassing experiments.

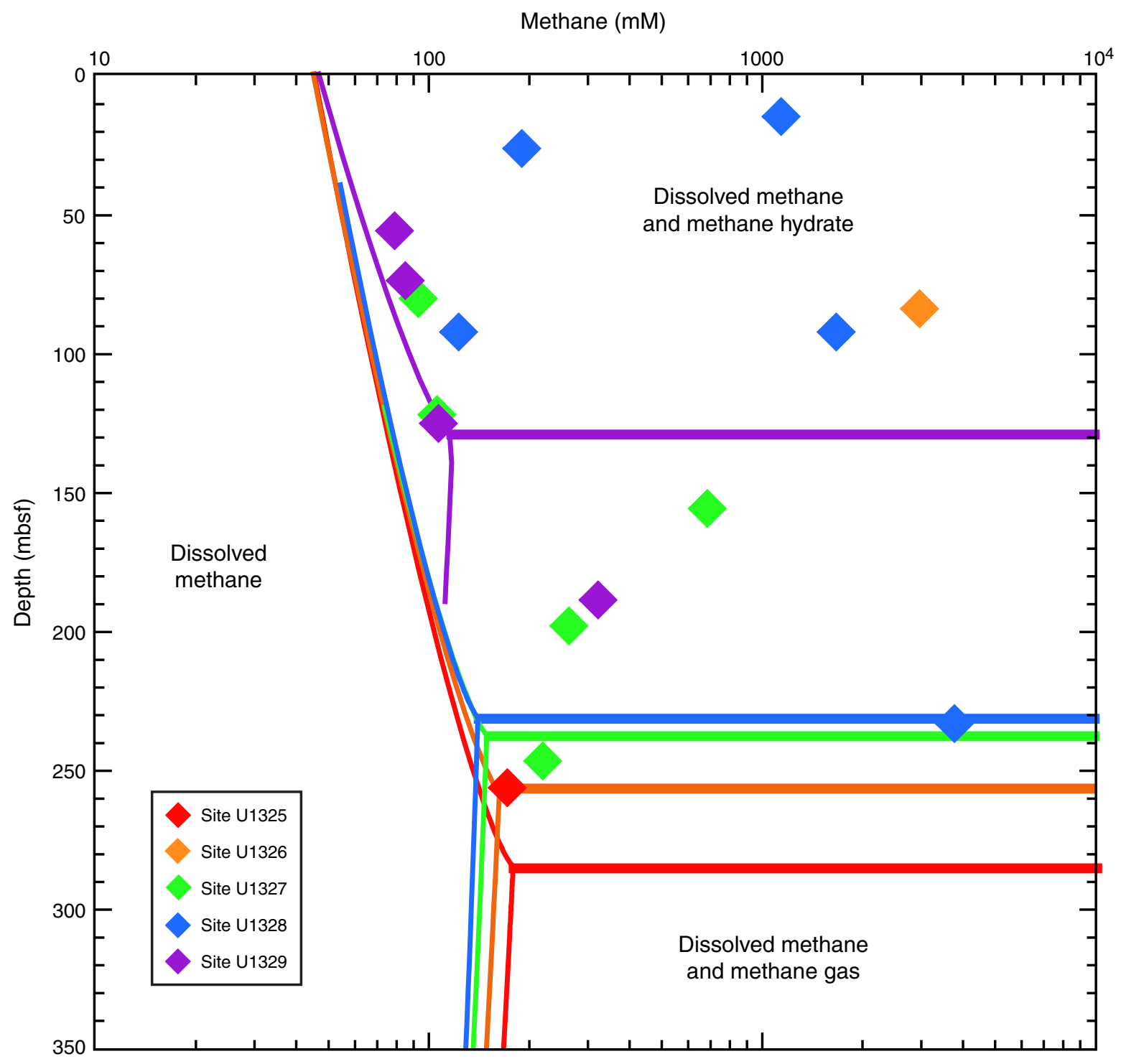


Figure F5. Comparison of pore water saturations $\left(S_{h}\right)$ calculated from logging-while-drilling (LWD) data. Shown for all sites are the main lithologic units (see "Lithostratigraphy" in all site chapters for definition of units), resistivity-at-the-bit (RAB) resistivity data, and $\mathrm{S}_{\mathrm{h}}$ estimates from Archie analyses. BSR = bottom-simulating reflector, PCS = Pressure Core Sampler.

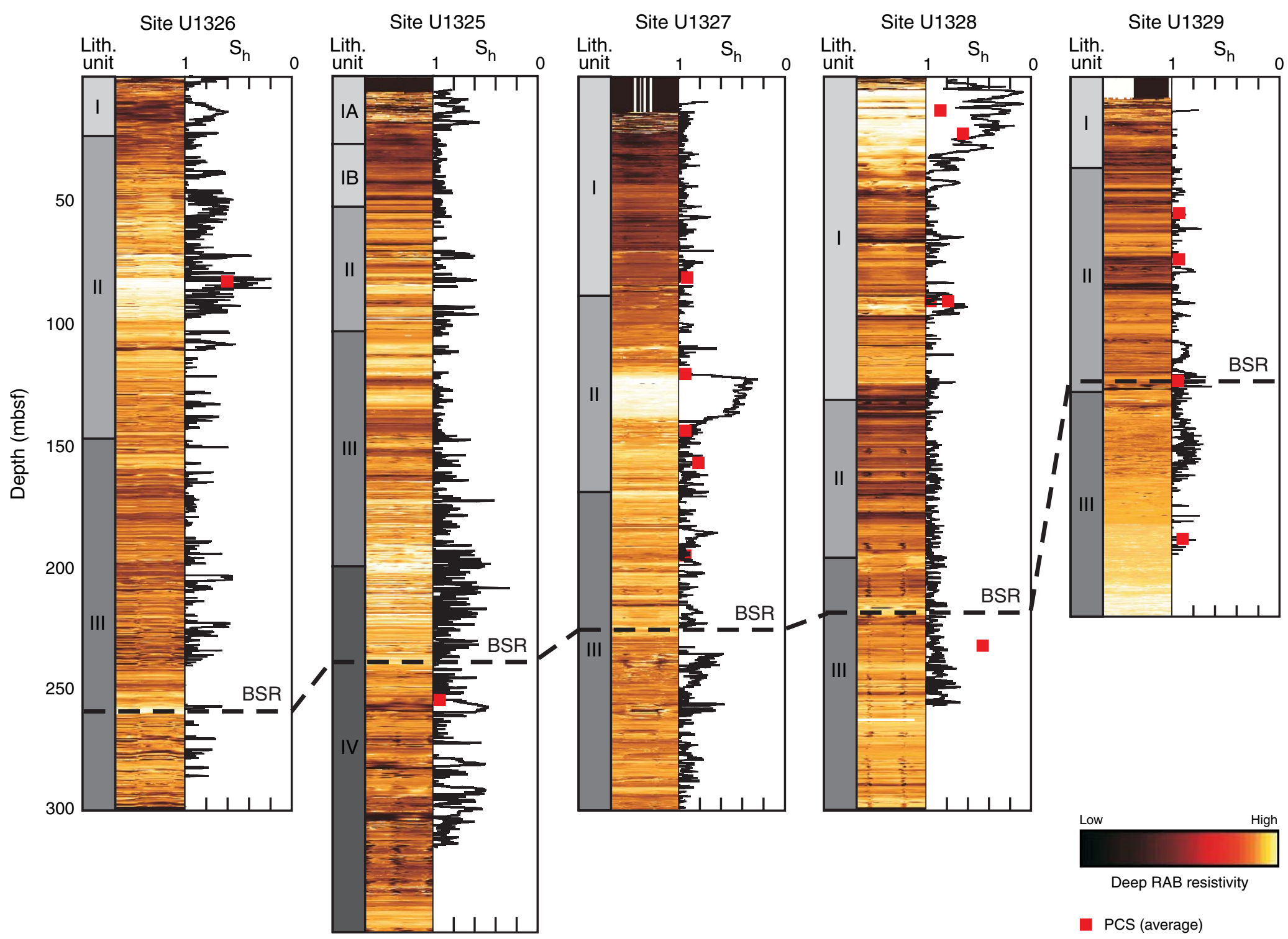


Figure F6. Comparison of logging-while-drilling (LWD) data with core-derived pore water chlorinity values. Shown for all sites are the main lithologic units, color-coded resistivity-at-the-bit (RAB) resistivity data, and pore water chlorinity from the recovered cores (blue) and pressure cores (red) as well as results from ODP Leg 146, Sites 889 and 890 (gray). BSR = bottom-simulating reflector, PCS = Pressure Core Sampler.
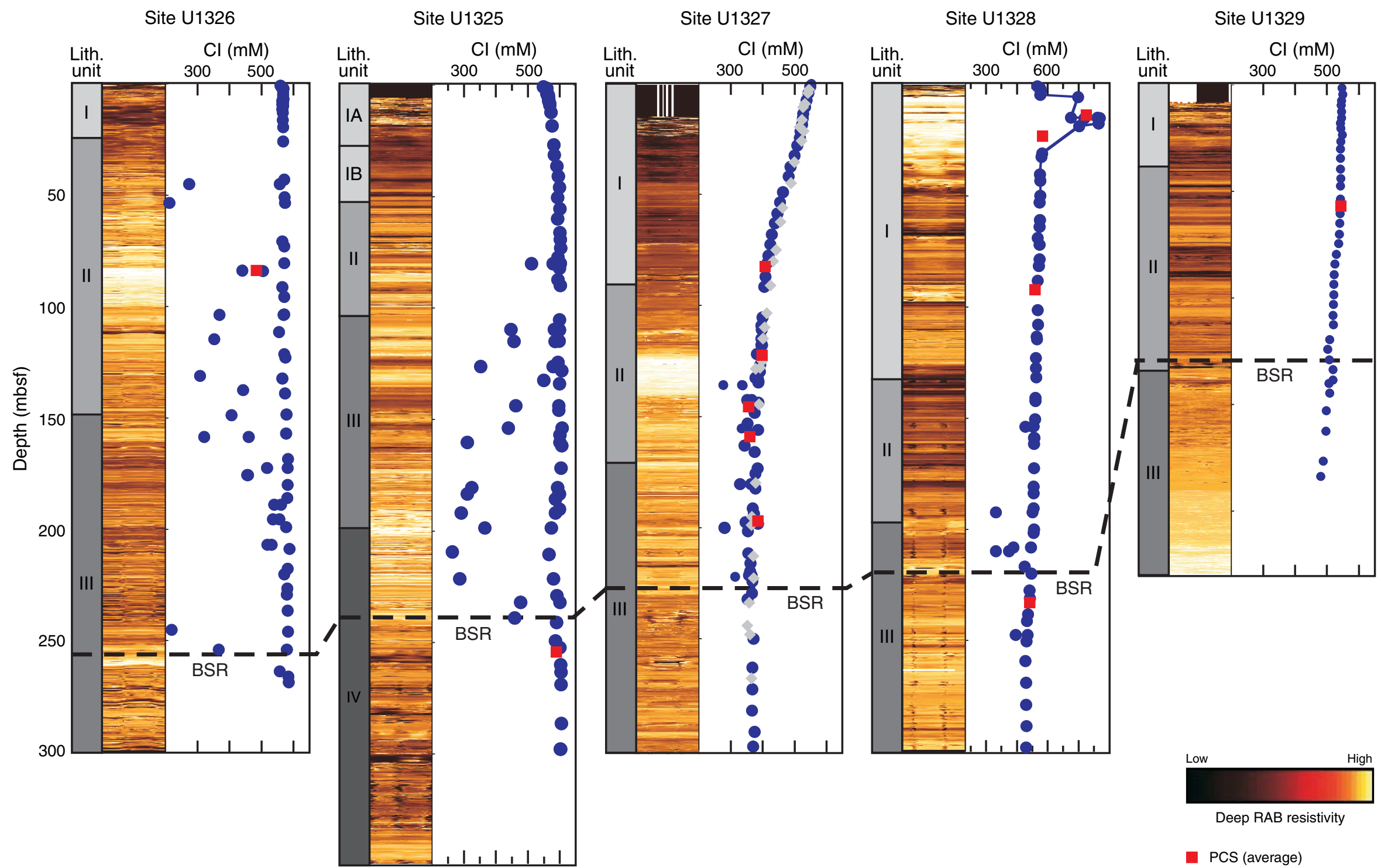

Deep RAB resistivity

PCS (average) 
Figure F7. Evidence for grain-size control on gas hydrate occurrence. A. Photograph of a recovered core at Site U1326 (311-U1326C-6X-4, 83-96 cm [44.85 mbsf]). B. Infrared (IR) image made in the geochemistry laboratory (modified after Torres et al., 2008). The IR temperature color scale is given on the right-hand side of the image. The sandy portion of the entire sample shown contains $\sim 70 \%$ gas hydrate in the pore space, as defined from pore water freshening compared to the assumed background, whereas the mud portion contains no gas hydrate (within the uncertainty of knowing the background salinity).
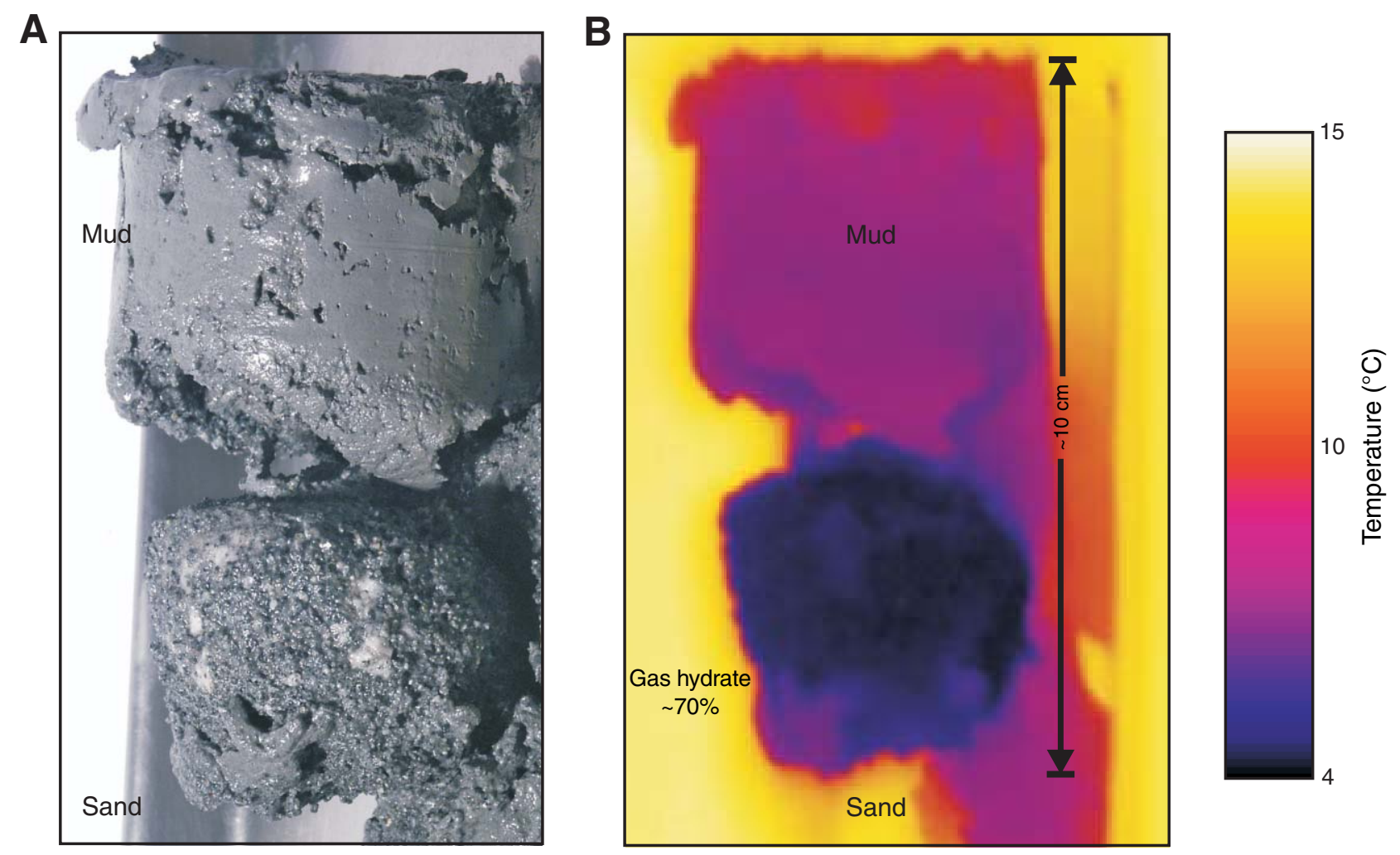
Figure F8. Comparison of fluid expulsion rates and total fluid expelled (as modeled by Hyndman and Davis, 1992) with observed total pore water freshening at a common depth of 200 mbsf observed at drill sites from ODP Legs 146 and 204 and IODP Expedition 311. SW = seawater.

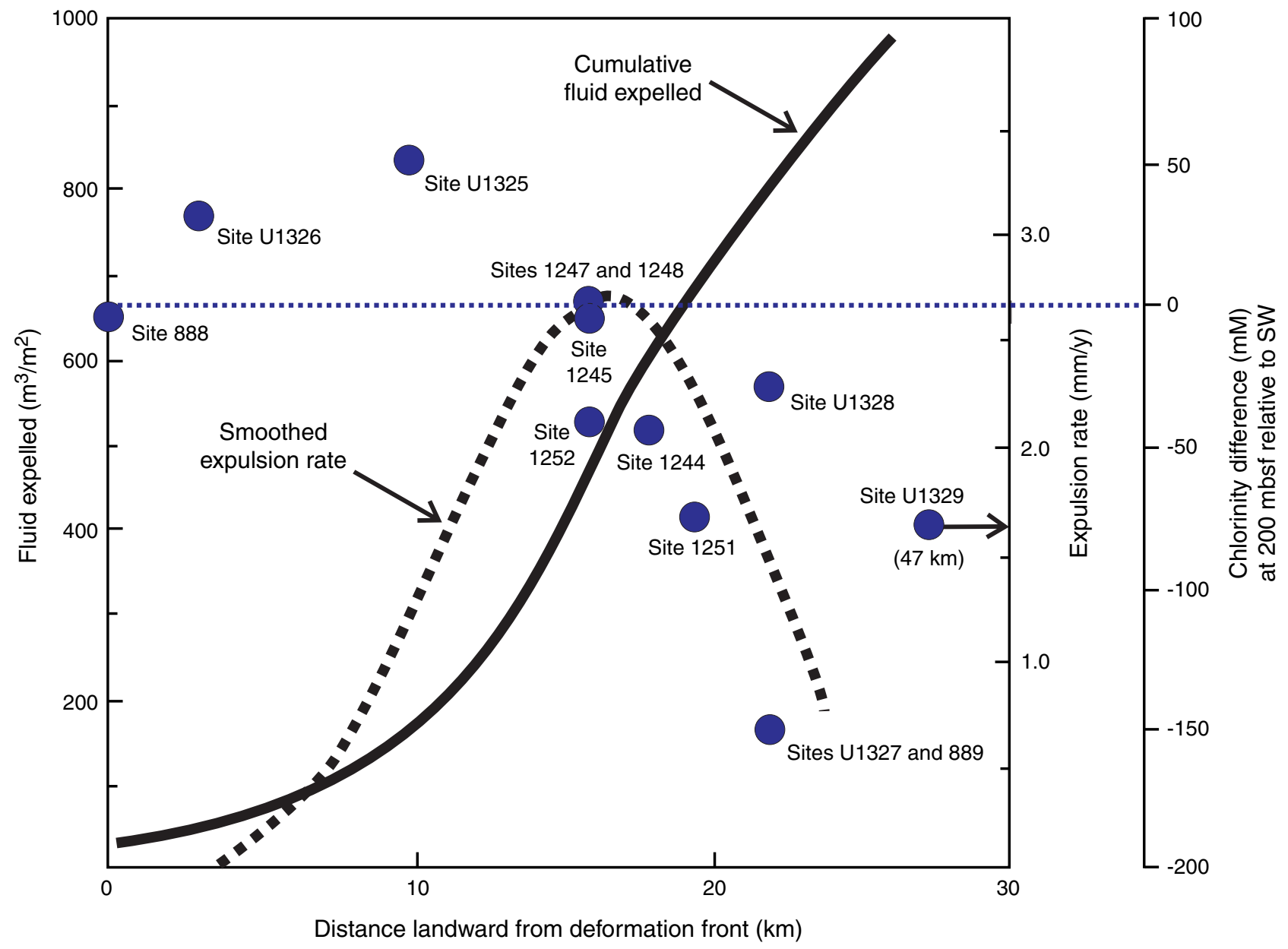


Figure F9. Depth profiles of lithium and strontium pore water data from the Expedition 311 transect. A. Lithium. B. Isotopic ratio of ${ }^{87} \mathrm{Sr} /{ }^{86} \mathrm{Sr}$. C. Strontium normalized to chlorinity. D. Mixing diagram of strontium data from Expedition 311 compared to results from ODP Leg 204 by Teichert et al. (2005). Unconf. = unconformity.

A

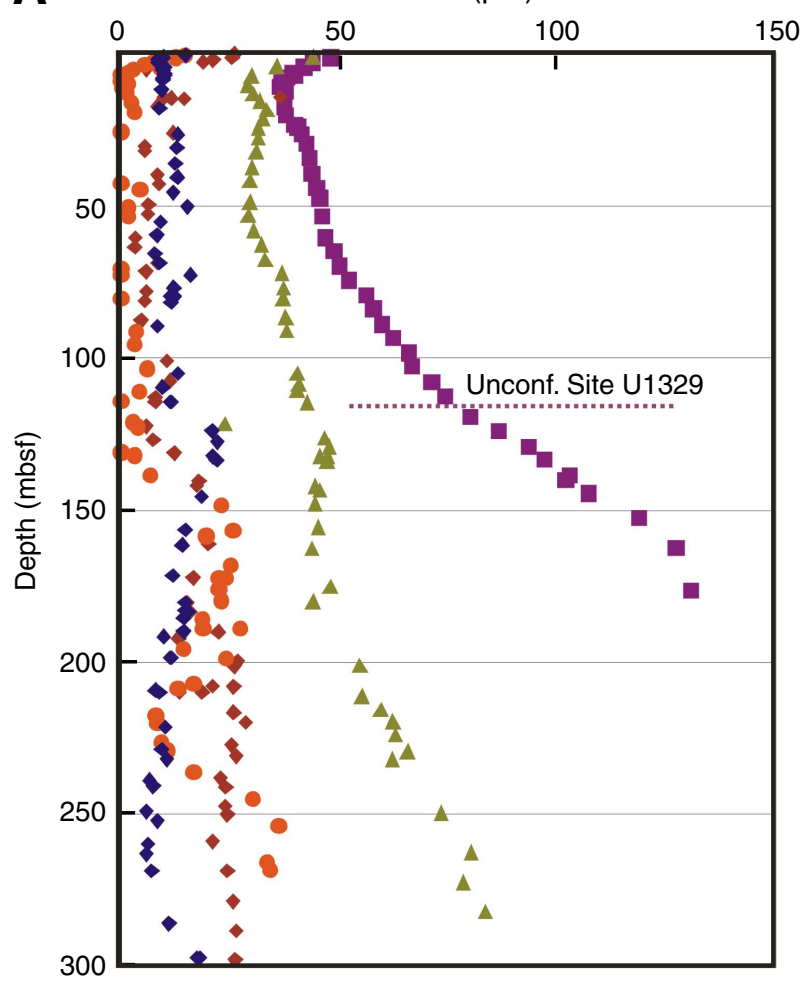

C

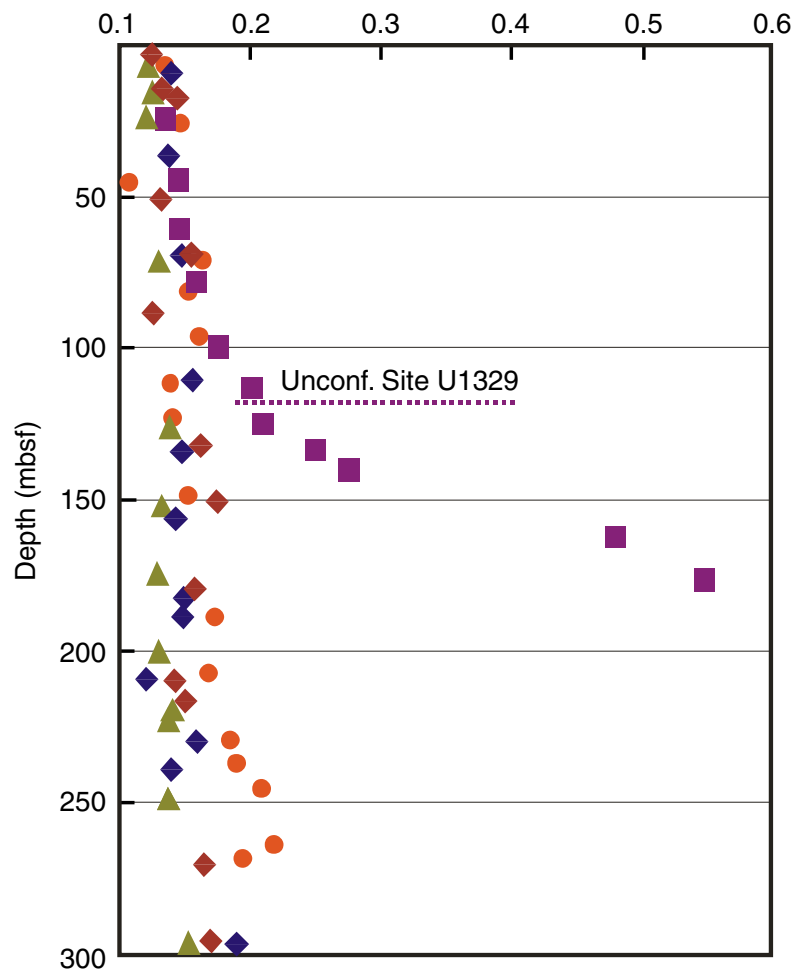

B ${ }^{87} \mathrm{Sr} / 86 \mathrm{Sr}$

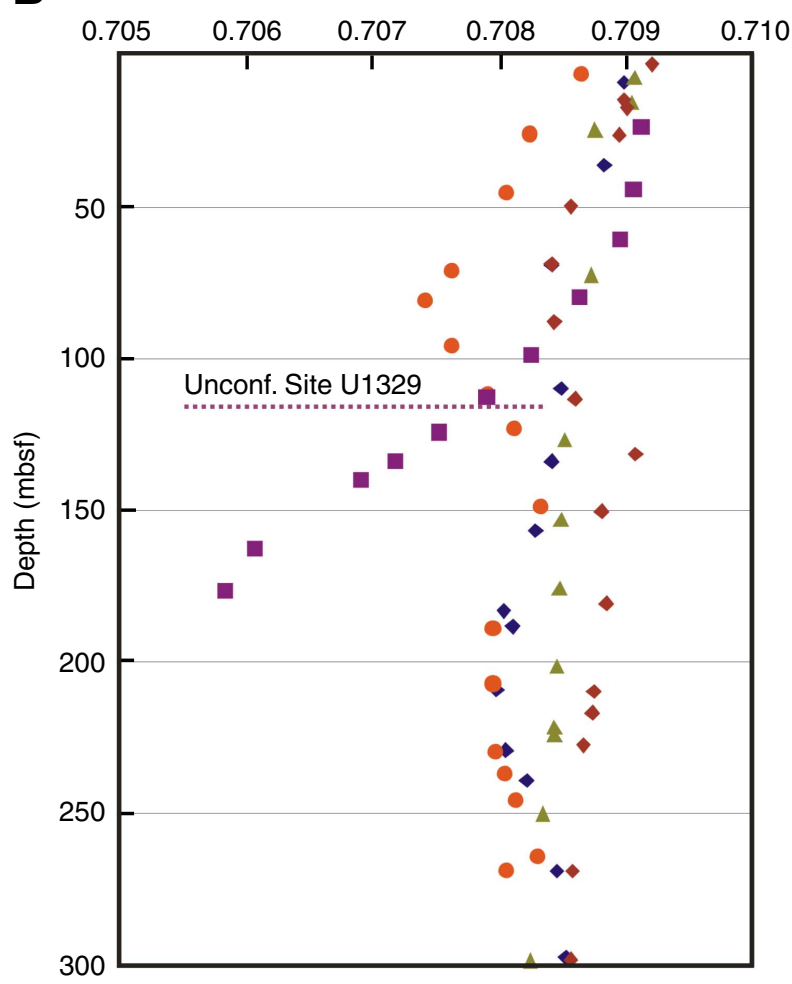

D

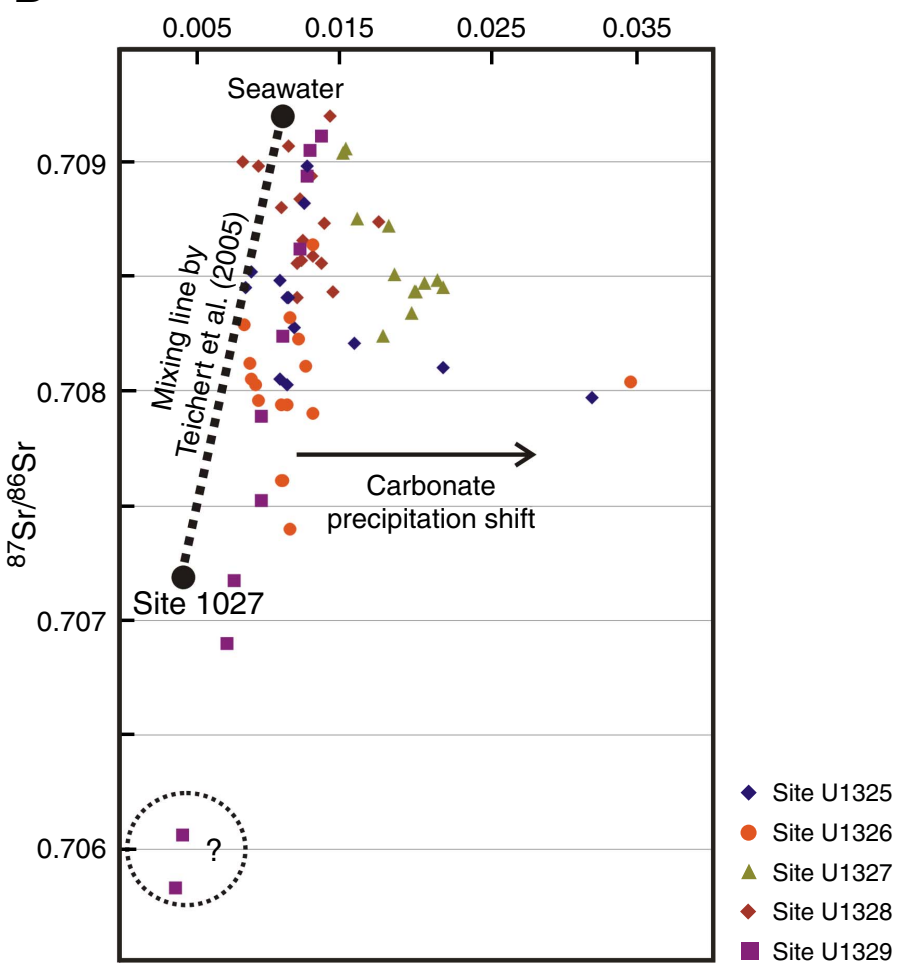


Figure F10. A. Depth profiles of the $\delta^{13} \mathrm{C}$ isotopic composition of methane and $\mathrm{CO}_{2}$ from all transect sites. Data from the vent Site U1328 are not included (from Pohlman et al., 2009). Also shown for reference are data from ODP Leg 146 Sites 888 and 889. B. Increase of the $\delta^{13} \mathrm{C}$ signature of dissolved inorganic carbon with distance from the deformation front. Data from ODP Legs 146 (Site 888) and 204 (Sites 1244, 1252, and 1251), and IDOP Expedition 311 (Sites U1326, U1325, U1327, and U1329) are combined (from Torres and Kastner). PDB = Peedee belemnite.
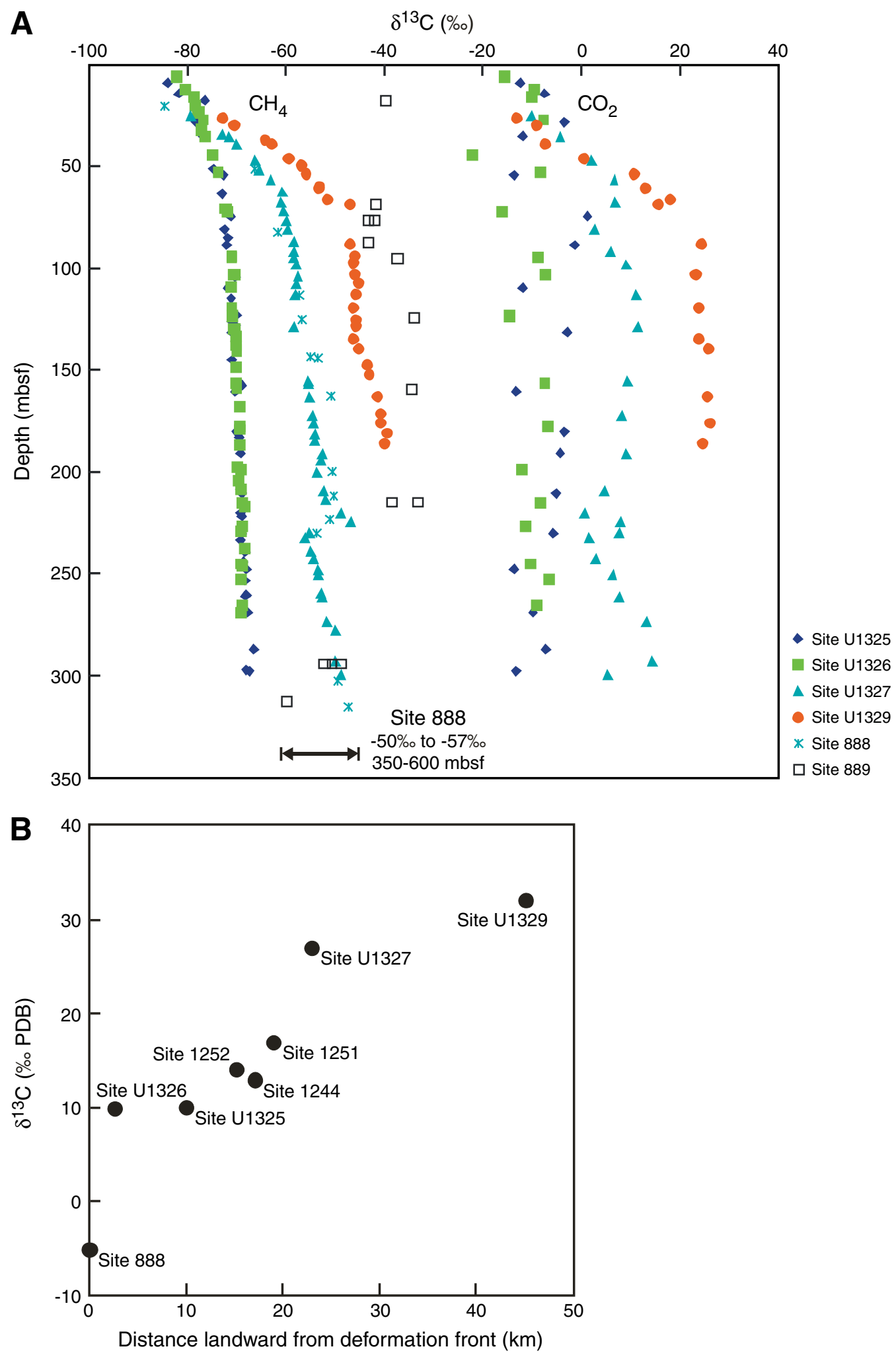
Figure F11. Downcore trend in the $\delta^{13} \mathrm{C}$ isotope composition of dissolved inorganic carbon (DIC) at Sites U1326 and U1325. Modified after Torres and Kastner. PDB = Peedee belemnite.

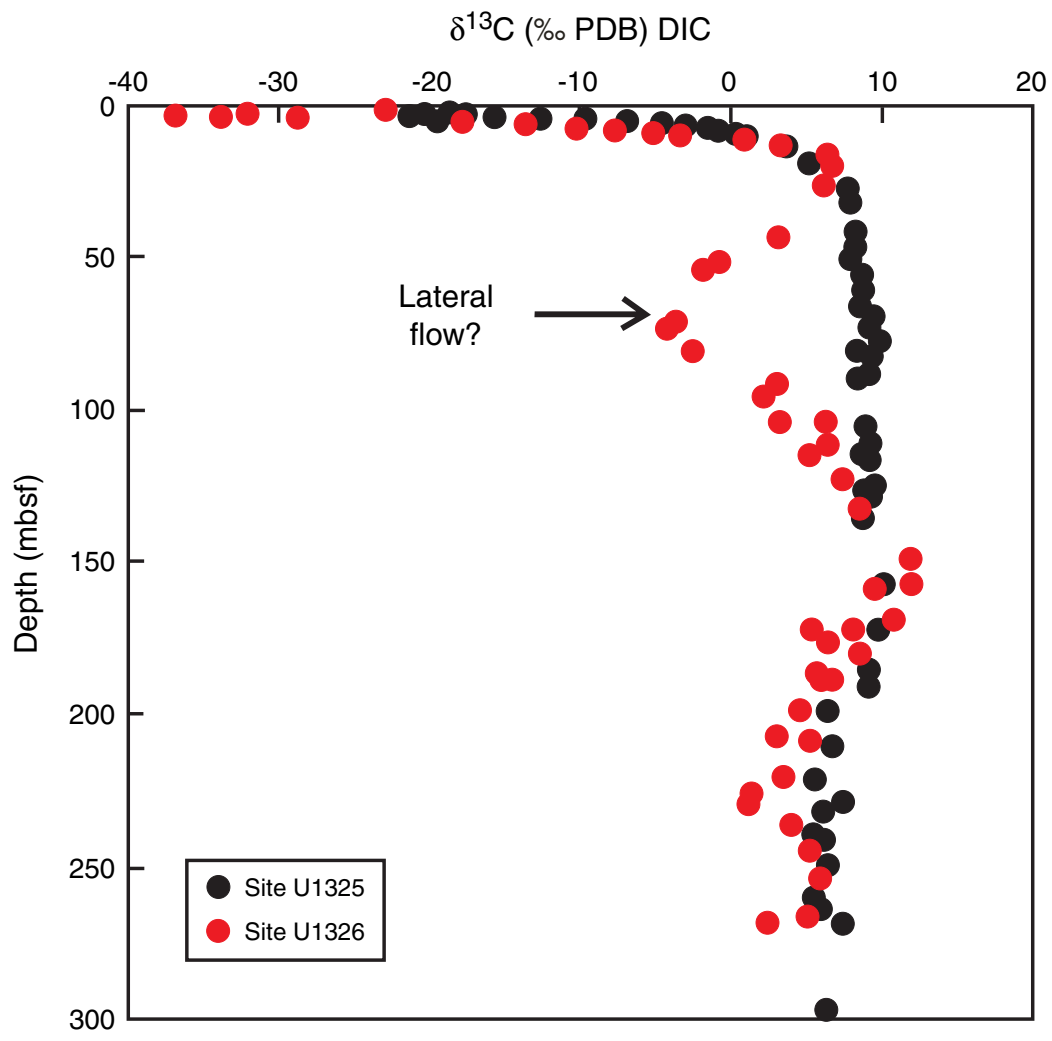


Figure F12. Schematic cartoon (not to scale) of the fluid flow and gas hydrate formation model for the northern Cascadia margin. See text for details. DF = deformation front, BGHS = base of gas hydrate stability, BSR = bottom-simulating reflector, $\mathrm{GH}=$ gas hydrate, $\mathrm{BGHSZ}=$ base of gas hydrate stability zone.

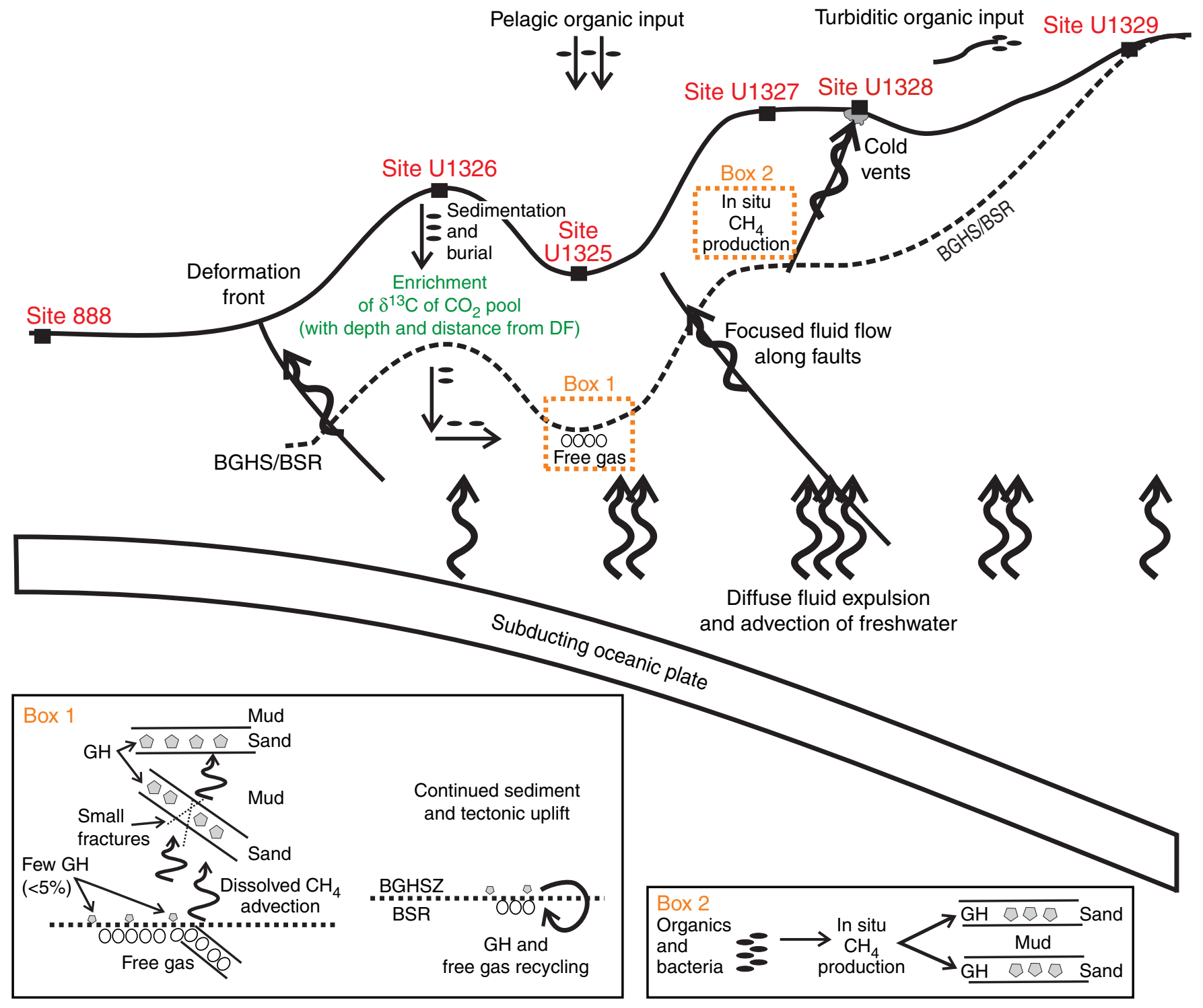


Table T1. Calculated depth of the base of gas hydrate occurrence (in meters below seafloor) from various geophysical and geochemical techniques. (See table notes.)

\begin{tabular}{|c|c|c|c|c|c|c|c|c|c|c|c|c|}
\hline \multirow[b]{2}{*}{ Technique } & \multicolumn{2}{|c|}{ Site U1325 } & \multicolumn{2}{|c|}{ Site U1326 } & \multicolumn{3}{|c|}{ Site U1327 } & \multicolumn{2}{|c|}{ Site U1328 } & \multicolumn{3}{|c|}{ Site U1329 } \\
\hline & U1325A & U1325C & U1326A & U1326D & U1327A & U1327D & U1327E & U1328A & U1328C & U1329A & U1329C & U1329D \\
\hline Precruise seismic BSR* & \multicolumn{2}{|c|}{230} & \multicolumn{2}{|c|}{234} & \multicolumn{3}{|c|}{223} & \multicolumn{2}{|c|}{219} & \multicolumn{3}{|c|}{125} \\
\hline Depth below seafloor (s) & \multicolumn{2}{|c|}{0.2817} & \multicolumn{2}{|c|}{0.2883} & \multicolumn{3}{|c|}{0.272} & \multicolumn{2}{|c|}{0.2673} & \multicolumn{3}{|c|}{0.154} \\
\hline LWD resistivity & 240 & $x$ & 260 & $x$ & 230 & $\mathrm{x}$ & $\mathrm{x}$ & 219 & $\mathrm{x}$ & ND & $x$ & $\mathrm{x}$ \\
\hline CWL computed velocity & $\mathrm{x}$ & DNRB & $\mathrm{x}$ & 260 & $x$ & $\mathrm{x}$ & 228 & $\mathrm{x}$ & 220 & $\mathrm{x}$ & $x$ & 125 \\
\hline CWL resistivity & $\mathrm{x}$ & DNRB & $\mathrm{x}$ & 260 & $\mathrm{x}$ & 235 & 235 & $\mathrm{x}$ & 220 & $\mathrm{x}$ & $x$ & 125 \\
\hline Deepest $\mathrm{Cl}^{-}$and IR anomaly & $\mathrm{x}$ & 238.9 & $\mathrm{x}$ & 264 & $\mathrm{x}$ & 222 & $x$ & $\mathrm{x}$ & 220 & $\mathrm{x}$ & 128 & $x$ \\
\hline $\mathrm{C}_{1} / \mathrm{C}_{2}$ & $\mathrm{x}$ & 243 & $\mathrm{x}$ & $\mathrm{x}$ & $\mathrm{x}$ & 225 & $\mathrm{x}$ & $\mathrm{x}$ & 214 & $\mathrm{x}$ & 119 & $\mathrm{x}$ \\
\hline $\mathrm{i}-\mathrm{C}_{4} / \mathrm{n}-\mathrm{C}_{4}$ or $\mathrm{C}_{3}$ & $\mathrm{x}$ & $\mathrm{x}$ & $\mathrm{x}$ & $\mathrm{x}$ & $\mathrm{x}$ & 225 & $\mathrm{x}$ & $\mathrm{x}$ & 219 & $\mathrm{x}$ & $x$ & $\mathrm{x}$ \\
\hline VSP & $x$ & $\mathrm{x}$ & $\mathrm{x}$ & $\mathrm{x}$ & $\mathrm{x}$ & 245 & $\mathrm{x}$ & $\mathrm{x}$ & ND & $\mathrm{x}$ & $\mathrm{x}$ & $\mathrm{x}$ \\
\hline Downhole thermal measurements & \multicolumn{2}{|c|}{$250-300$} & \multicolumn{2}{|c|}{$250-270$} & \multicolumn{3}{|c|}{$225-250$} & \multicolumn{2}{|c|}{$220-245$} & \multicolumn{3}{|c|}{$127-129$} \\
\hline Best estimate of BGHSZ: & \multicolumn{2}{|c|}{240.5} & \multicolumn{2}{|c|}{264} & \multicolumn{3}{|c|}{230} & \multicolumn{2}{|c|}{219} & \multicolumn{3}{|c|}{124} \\
\hline
\end{tabular}

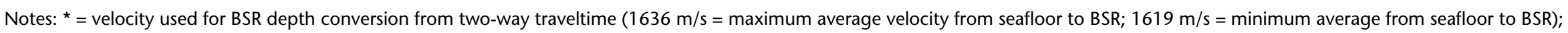
reported depth is the average of minimum and maximum estimates (note that velocity was determined from VSP at ODP Site 889 ). BSR $=$ bottom-simulating reflector, LWD $=$ loggingwhile-drilling, $C W L=$ coring-while-logging, IR = infrared, $V S P=$ vertical seismic profile, $B G H S Z=$ base of gas hydrate stability zone, $N D=$ not detected, $D N R B=$ wireline logging tools did not reach BSR depth. Deepest chloride and IR anomaly: Hole U1326D: salinity of sample at 263.63 mbsf is 32 (baseline = 33.5); the next shallowest anomaly (salinity = 23) is at $253.61 \mathrm{mbsf}$ (no indication of s-II hydrate); Hole U1327D: salinity of two samples at $221.96 \mathrm{mbsf}$ is 3.7 and 18 , respectively (background = 22); Hole U1328C: salinity of sample at 216.5 mbsf is 28 (background = 31); Hole U1329C = freshening spike in chlorinity (not salinity) between 119 and $128 \mathrm{mbsf}(502-508 \mathrm{mM}$ over a background of $\sim 520 \mathrm{mM}$ ). Break in slope of $C_{1} / C_{2}$ ratios: Hole U1325C: below 243.85 mbsf $\left(C_{1} / C_{2}>60,000\right.$ above; $C_{1} / C_{2}<20,000$ below); Hole U1327D: in void gas at 225 mbsf; Hole U1328C: between 209.3 ( $C_{1} / C_{2}>$ $10,000)$ and $217.7 \mathrm{mbsf}\left(\mathrm{C}_{1} / \mathrm{C}_{2}<1,500\right)$; Hole U1329C: at $119.3 \mathrm{mbsf}$. Break in slope of $\mathrm{i}-\mathrm{C}_{4} / \mathrm{n}-\mathrm{C}_{4}$ at $224.62 \mathrm{mbsf}$ in Hole U1327D. i- $\mathrm{C}_{4}$ enriched samples at 207.1 and 209.3 mbsf and $\mathrm{C}_{3}$ enriched samples at 217.1 and 218.8 mbsf in Hole U1328C; values are much lower below. Best estimate of BGHSZ: Sites U1325 and U1327-U1329: simple average value, rounded to nearest $0.5 \mathrm{~m}$. Site U1326: deepest chlorinity anomaly is deeper than all other proxies, but there is no indication of s-II gas hydrate. 